\title{
Bank Capital, Borrower Power, and Loan Rates
}

\author{
João A. C. Santos* \\ Federal Reserve Bank of New York \& Nova School of Business and Economics \\ 33 Liberty St. \\ New York, NY 10045 \\ Tel: (212) 720-5583 \\ E-mail: joao.santos@ny.frb.org \\ Andrew Winton* \\ Carlson School of Management \\ University of Minnesota \\ 321-19th Avenue South \\ Minneapolis, MN 55455 \\ Tel: (612) 624-0589 \\ E-mail: awinton@csom.umn.edu
}

July 1, 2018

\footnotetext{
*The authors thank Philip Strahan (the editor) and two anonymous referees, as well as Mark Flannery, Murray Frank, Erasmo Giambona, Radha Gopalan, Florian Heider, Evren Ors, Daniel Paravisini, Steve Sharpe, James Vickery, Tracy Wang, and seminar participants at the ECB, the Federal Reserve Banks of Kansas City and New York, the Federal Reserve Board of Governors, Erasmus University of Rotterdam, Louisiana State University, Tilburg University, the University of Minnesota, the 2009 Federal Reserve Bank of Chicago's Bank Structure Conference, the 2009 EFA Meetings, the 2010 AFA Meetings, the 2010 FIRS Meetings, the 10th FDIC/JFSR Bank Research Conference, and the 2010 Conference on Financial Economics and Accounting for valuable comments. The authors also thank Ben Iverson for outstanding research assistance. The views stated herein are those of the authors and are not necessarily those of the Federal Reserve Bank of New York, or the Federal Reserve System.
} 


\title{
Bank Capital, Borrower Power, and Loan Rates
}

\begin{abstract}
We examine how bank capital and borrower bargaining power affect loan spreads. Consistent with previous studies, higher bank capital has a negative impact on loan rates, but borrower cash flow has a significant effect on this impact: compared to high-capital banks, low-capital banks charge more for borrowers with low cash flow, but offer greater marginal discounts as these borrowers' cash flow rises. These effects are largely focused on borrowers that are more bank-dependent. We find some evidence that low-capital banks charge a higher premium for bank-dependent borrowers' systematic risk, but not for their total equity risk or default risk.
\end{abstract}




\section{Introduction}

The link between bank capital levels and lending behavior is critically important to policy makers seeking to oversee the health of the banking system and its impact on the wider economy. It is widely believed that, both in the early 1990s and in the financial crisis of 20082009, low bank capital levels caused by large credit losses contributed to significant cutbacks in bank lending to businesses and others - so-called "credit crunches". In the aftermath of the crisis, the debate over whether and how much to raise required bank capital levels has focused on how such requirements will affect bank lending. A better understanding of the link between bank capital and loan rates can further our understanding of bank behavior, aid borrowers' in assessing the risks of bank capital shortfalls, and help guide policy makers in crafting and enforcing bank regulations.

Our paper takes a fresh look at this issue, focusing on how bank capital and its interactions with borrower attributes such as bank-dependence, risk, and cash flow affect lending rates for publicly-traded U.S. firms during $1987-2007 .{ }^{1}$ To design our tests, we build on theories that emphasize banks' ability to exert monopoly power over bank-dependent borrowers and the role of bank capital in amplifying or mitigating such behavior. In these theories, banks have the ability to charge bank-dependent firms higher rates than non-dependent firms, but exactly what they charge in equilibrium depends on the interplay between the bank's incentives and the borrower's relative bargaining power. In Boot, Greenbaum, and Thakor (1993), low capital makes the bank more willing to exploit borrowers so as to replenish capital with retained earnings, even though this hurts the bank's reputation for honoring implicit agreements. In Froot and Stein (1998), low capital makes a bank more risk averse, and so it will either charge riskier borrowers a higher rate or else let them seek out other funding sources. In Diamond and Rajan (2000), low capital makes the bank demand immediate liquidity to forestall depositor runs, which strengthens its bargaining power vis-à-vis borrowers with low cash flow but weakens its bargaining power vis-à-vis borrowers with high cash flow.

To better frame our analysis, we begin with regressions of borrower loan spreads versus

\footnotetext{
${ }^{1}$ Although there has been a large body of empirical work on this topic, previous studies have tended to look at bank-level data on total loan balances rather than specific loans and their terms. Two exceptions to this are Hubbard, Kuttner, and Palia (2002) and Mattes, Steffen, and Wahrenburg (2013). We discuss our relation to this literature in the next section.
} 
a variety of controls for our entire sample. These regressions reveal a significantly negative relationship between a bank's capital/assets ratio ("bank capital") and the loan spread. When we introduce the interaction between borrower cash flow and bank capital as an additional explanatory variable, the coefficient on bank capital becomes even more negative while that on the interaction is significantly positive. These results are robust.

Although these results match the broad outlines of the three theories mentioned above, all of these theories argue that these results should hold most strongly for bank-dependent borrowers. Accordingly, we divide our overall sample into borrowers that are bank-dependent and those that are not bank-dependent ("non-dependent") at the time of the loan. Using six alternative definitions for bank dependence - three based on measures that indicate the borrowing firm has limited access to public debt markets, and three are based on the degree to which the firm has recently relied on one bank for its loans - we rerun our baseline specification (with bank capital and its interaction with borrower cash flow) on these subsamples. We find that the effects of bank capital and the interaction term are stronger on bank-dependent subsamples than they are for the combined sample; moreover, the effects are strongest for the most stringent definitions of bank-dependence. By contrast, these two effects are generally insignificant for the non-dependent subsamples.

The effects we find are significant not only statistically but also economically. For bank-dependent borrowers with cash flows one standard deviation below the mean, a change in bank capital from one standard deviation below to one standard deviation above the mean reduces loan rates by roughly 16 to 20 basis points, whereas for bank-dependent borrowers with cash flows at the mean, the same change in bank capital reduces loan rates by only 6 to 11 basis points. By contrast, for borrowers with cash flows one standard deviation above the mean, changes in bank capital have statistically and economically insignificant effects on loan rates. To put these numbers in perspective, the average loan spread in our sample is 171 basis points.

To see whether the cash flow-capital interaction effect reflects a borrower's relative bargaining power based on liquidity concerns or instead measures the borrower's risk and thus its cost to risk-averse low-capital banks, we augment our specification with interactions between bank capital and one of three borrower risk proxies: the borrower's stock return volatility, its estimated probability of default, and its equity beta. Interactions of bank capital 
with borrower volatility or borrower default probability are generally insignificant, but the interaction between bank capital and borrower beta is negative and somewhat significant for bank-dependent borrowers and generally insignificant for non-dependent borrowers. Regardless of the risk proxy used, however, the impact of borrower cash flow and its interaction with bank capital are basically unchanged from the earlier regressions.

The upshot is that low-capital banks place a greater premium on low borrower cash flow than high-capital banks do, but this difference is concentrated on bank-dependent borrowers. There is weak evidence that they also place a greater premium on bank-dependent borrowers' systematic risk than high-capital banks do, and no evidence that their pricing of borrowers' other risk is different from that of high-capital banks. These results are consistent with the model of Diamond and Rajan (2000), which predicts that low-capital banks extract greater rents from low-cash-flow borrowers because they have a more credible threat to liquidate the loan than high-capital banks do. A related explanation that builds on Boot et al. (1993) is that low-capital banks charge premia for low-cash-flow as an abrogation of implicit contracts with relationship borrowers, because such borrowers represent a greater drain on bank resources and have limited bargaining power; instead, high-cash-flow borrowers are effectively not very bank-dependent, and get charged similar rates from high- and low-capital banks. By contrast, our results only weakly support Froot and Stein's (1998) prediction that low-capital banks are effectively more risk averse and so charge a higher risk premium for risk that they cannot diversify or offload via loan sales.

Throughout our analysis, we impose a number of controls to rule out alternative explanations for our results. We include a proxy for market-wide credit spreads and its interaction with bank capital. In the regressions with interactions between bank capital and borrower cash flow or risk, we also interact the market-wide credit spread with these borrower variables. This helps rule out spurious correlation, when bank capital levels and possibly the importance of borrower risk or cash flow for loan pricing are independently driven by common credit market conditions. Also, all of our regressions include bank and year-quarter fixed effects, with errors clustered by firm and by bank. ${ }^{2}$ Thus, the effect of capital reflects a bank being above or below its long-run mean capital level, rather than its being above or below the sample mean capital level. This helps rule out the possibility that our results are driven by different banks having

\footnotetext{
${ }^{2}$ See Petersen (2009) for a discussion on the importance of clustering errors.
} 
both different loan focus and different desired capital levels.

Another possible explanation for the negative impact of higher bank capital on lending rates is selection, where banks with low capital seek out or attract riskier borrowers than do banks with high capital. Several points weigh against this. First, we include a large number of firm controls in our regressions. As a test, we predict loan spreads based on all of our control variables except bank capital, and then regress this predicted spread on bank capital. The relationship is strongly positive, suggesting that observably riskier borrowers are catered to by banks with higher capital, not lower capital. Second, our inclusion of bank fixed effects means that our results are not caused by unobservable time-independent selection between a given bank and its borrowers. Third, such a selection mechanism is not consistent with our finding that low-capital banks not only charge low-cash-flow borrowers higher rates than high-capital banks do, but also charge high-cash-flow borrowers rates that are the same or even lower than high-capital banks do: if low-capital banks were seeking to take on additional risk, they would not give discounts to high-cash-flow borrowers. Fourth and finally, our results are robust to including bank-year-quarter fixed effects rather than independent bank fixed effects and yearquarter fixed effects, which rules out sorting based on some unobservable variation in each bank's risk preferences over time.

The rest of the paper is structured as follows. Section 2 discusses related literature. Section 3 discusses out data and empirical methodology. Section 4 contains our main results. Section 5 addresses possible selection and endogeneity concerns, and Section 6 briefly describes additional robustness tests. Section 7 concludes our paper.

\section{Related Literature}

The three theoretical papers on bank capital and lending that are most relevant to our work are Boot, Greenbaum, and Thakor (1993), Froot and Stein (1998), and Diamond and Rajan (2000). In this section, we discuss these three papers in somewhat more detail and then discuss related empirical literature.

All three theory papers examine settings where raising additional bank capital is costly and then show that having low capital may distort banks' lending behavior, especially for bank-dependent borrowers. Boot, Greenbaum, and Thakor (1993) show that banks with low financial capital may sacrifice reputational capital by reneging on implicit guarantees in order 
to increase their profits and thus their financial capital. Retaining this flexibility allows banks to economize on raising additional costly capital in situations where their financial capital is unexpectedly low. Although Boot et al. focus on credit guarantees with an "escape clause" (such as a Material Adverse Change Clause), their trade-off should also apply to the pricing of loans to bank-dependent firms. As shown by Sharpe (1990) and Rajan (1992), such firms find it costly to switch to other sources of financing, giving their current bank monopoly power over them. Because exploiting this information monopoly leads to inefficient borrower behavior, the bank may implicitly commit to avoid such exploitation unless its need for short-term profits (due to low financial capital) outweighs the damage to its reputation for honoring such commitments. By contrast, for "non-dependent" borrowers who do not face such monopoly power, these reputational concerns should not arise because the bank has no power to exploit in the first place.

Froot and Stein (1998) look at bank portfolio choice and pricing when some assets (e.g., loans) are illiquid and it is costly to raise additional bank capital. When external capital is costly, Froot, Scharfstein, and Stein (1993) show that firms choosing over positive NPV projects will behave in a risk-averse fashion, with an effective risk aversion that increases as their initial net worth is lower. Applying this framework to banks, Froot and Stein (1998) show that the rates banks charge on risky illiquid assets should include an additional premium over and above the rates on liquid assets. This premium increases with the assets' covariance with the bank's illiquid portfolio and decreases as the bank's capital increases. By contrast, assets that are fully liquid will only be subject to market-wide risk premia, which are independent of the bank's capital ratio. To the extent loans to non-dependent firms face fewer information asymmetries than loans to bank-dependent firms, Froot and Stein's risk premium should apply most forcefully to the latter.

Diamond and Rajan (2000) model bank capital in a setting where bank depositors' ability to withdraw funds disciplines bank managers, but exposes banks to costly runs when depositors face exogenous liquidity shocks. Higher bank capital reduces the threat that exogenous liquidity shocks will lead to such runs; conversely, banks with lower capital face a higher chance of such runs and thus have a greater need to bolster their liquidity so as to forestall them. It follows that bank capital affects the terms on which the bank will refinance those borrowers with which it has a relationship. Compared to a high-capital bank, a low-capital 
bank's need for cash gives it a more credible threat to liquidate low-cash-flow borrowers now. Knowing this, low-cash-flow borrowers will be willing to pay more to low-capital banks so as to avoid liquidation. By contrast, a low-capital bank's need for cash weakens its bargaining position when facing a high-cash-flow borrower - the borrower can extract weaker lending terms in return for paying off some of its debts earlier. It follows that, relative to a high-capital bank, a low-capital bank should charge higher rates to firms with low-cash flows, and possibly lower rates to firms with high cash flows. Note that it is critical that the borrower is bank-dependent; otherwise, a low-cash borrower could seek refinancing from other high-capital banks without penalty, leaving the low-capital bank unable to extract rents.

Although there is a large body of empirical work on how bank capital affects bank lending activity, relatively little has focused on the bargaining power effects that are the focus of the three theory papers just described. An early literature, motivated by the "credit crunch" of the early 1990s, examined the relationship between a bank's capital ratio and its total loans: examples include Berger and Udell (1994), Hancock and Wilcox (1993, 1998), Peek and Rosengren (1995), and Beatty and Gron (2001). These studies tend to find that, to the extent bank capital and lending are linked, they seem to be complements rather than substitutes (low capital banks reduce loans relative to safer assets) and the effects are concentrated at banks with low capital. Peek and Rosengren (1995) also find that reductions in lending are greatest for loan categories in which bank-dependent borrowers are most common. A common drawback of these papers is that they look at total outstanding loans (possibly by loan sector) rather than loans to individual firms. This approach makes it hard to see whether the impact of bank capital varies across borrowers with different attributes - a crucial omission, because banking theory suggests that some borrowers are likely to be more dependent on banks, and thus more subject to the effects of bank capital changes on lending policy.

Two more recent papers have used loan-level data to analyze the tradeoff between banks' reputational and financial capital predicted by Boot, Greenbaum, and Thakor (1993). Hubbard, Kuttner, and Palia (2002) examine the pricing of U.S. bank loans to publicly-traded firms during the period 1987 to 1992. Using lack of a debt rating and small size as proxies for higher borrower switching costs based on information problems, they find that low-capital banks charge higher rates than other banks, but only to borrowers in the high switching-cost groups. Mattes, Steffen, and Wahrenburg (2013) examine a sample of U.K. loans to both 
publicly-held and privately-held firms during the period 1996 to 2005. Like Hubbard, Kuttner, and Palia (2002), they find that low-capital banks charge higher rates to privately-held (high switching-cost) firms than to publicly-held firms, but this effect only occurs during economic downturns. This is consistent with banks needing financial capital more in downturns, causing them to consume reputational capital by charging higher spreads during those periods.

Our analysis is also related to work that investigates the importance of banks' informational advantage vis-á-vis their borrowers. Santos and Winton (2008) find that, controlling for risk, borrowers without public debt market access pay higher rates than borrowers with such access, and this difference increases during recessions, when banks are likely to have greater information monopoly rents from bank-dependent borrowers. Schenone (2010) finds that borrowers pay higher rates before their equity IPO than after their IPO; she argues that this effect is linked to bank information monopolies. Similarly, Hale and Santos (2009) find that borrowers pay lower loan rates after they undertake their bond IPO; they argue that this decline reflects a reduction in bank information monopolies.

Our paper differs from these earlier strands in several respects. Like Hubbard et al. and Mattes et al., we are interested in how bank capital levels affect pricing. However, rather than using an indicator for low bank capital based on a bank's capital level relative to the overall sample, we focus on a continuous measure of bank capital relative to that bank's mean capital level. As stated in the introduction, this enables us to rule out several alternative explanations for our results. We also examine the interaction between our bank capital measure and various proxies for borrower risk and cash flow. Finally, we use a broader set of proxies for bankdependence than these earlier papers. This is critical, because our results turn out to be strongest when we use a measure of bank-dependence that focuses on the intensity of the bank-borrower relationship rather than access to public debt markets per se.

\section{Data, methodology and sample characterization}

\subsection{Data}

The data for this project come from several sources. We use the Loan Pricing Corporation's (LPC) Dealscan database of business loans to identify the firms that borrowed from banks, and to obtain information on their loans and lending syndicates. Most but not all of the loans 
in this database are syndicated. LPC goes back to the beginning of the 1980s; in the first part of that decade it was not very comprehensive, but this has improved steadily over time. It is for this reason that we begin our sample in 1987.

Our sample ends in June 2007, before the start of the recent financial crisis. The crisis was a once-in-a-few-generations event, during which questions of interbank spillovers and government policy and intervention loomed much larger than in normal times, or even "normal" crises. At a minimum, the crisis is a very different regime than our sample period and calls out for separate analysis. Moreover, none of the theories that are the foundation for our analysis explicitly incorporate interbank spillovers or uncertainty over government intervention. Thus, our analysis complements the large literature on bank-specific effects in the crisis by showing that bank capital exerts important effects even in normal times. ${ }^{3}$

We rely on the Securities Data Corporation's (SDC) Bond Issuances database to identify which firms in our sample issued bonds prior to borrowing in the syndicated loan market. We also rely on this database to identify some features of the bonds issued by the firms, including their issuance date, their credit rating, and whether they were publicly placed.

We use Compustat to get information on firms' balance sheets. Even though LPC contains loans from both privately-held and publicly-held firms, Compustat is dominated by publicly-held firms. Thus, we exclude loans to privately-held firms from our sample.

We use the Center for Research on Securities Prices's (CRSP) stock prices database to link companies and subsidiaries that are part of the same firm, and to link companies over time that went through mergers, acquisitions or name changes. We then use these links to merge the LPC, SDC and Compustat databases, giving us the financial condition of the firm at the time it borrowed from banks and whether the firm had already issued bonds before then. We also use CRSP to determine each borrower's excess stock return, stock return volatility, and beta. Our main measure of beta is calculated by regressing a firm's daily stock returns on the S\&P 500 Index over the previous two years; however, as noted in Section 5, as a robustness test we also use weekly and monthly betas calculated over the previous two years.

We rely on the Salomon Brothers/Citigroup yield indices on new long-term industrial

\footnotetext{
${ }^{3}$ Examples of how bank-specific conditions affected corporate lending during the crisis include Santos (2011), who focuses on banks' financial condition, and Ivashina and Sharfstein (2010) and Cornett et al. (2011), who focus on banks' exposure to unused credit lines.
} 
bonds to control for changes in the market's credit risk premium. We use the yield difference between the indices of triple-A and triple-B rated bonds because these indices go back to the beginning of our sample.

Finally, we use the Reports of Condition and Income compiled by the FDIC, the Comptroller of the Currency, and the Federal Reserve System to obtain bank data for the lead bank(s) in each loan syndicate. ${ }^{4}$ Wherever possible we get this data at the bank level from the Call Reports. If these reports are not available, then we rely on the Y9C Reports, which have data at the bank holding company level.

\subsection{Defining bank-dependent and non-dependent firms}

We use six different definitions of bank-dependence. The first three definitions focus on the borrower's degree of access to public debt markets. Because firms with such access have a broader array of sources of funds, they are likely to be less dependent on banks for financing; moreover, the fact that their debt is publicly traded should decrease the amount of private information that their bank lenders have, reducing the extent to which banks can exploit information monopolies a la Sharpe (1990) and Rajan (1992). Accordingly, our first three splits classify firms as bank-dependent based on whether they (1) do not have a commercial paper rating, (2) do not have a bond credit rating, or (3) have not issued a public bond in the last three years. In each case, firms that do not meet the criterion are classified as nondependent. Following Santos and Winton (2008), we do not count privately-placed bonds as a measure of public bond market access. We believe private placements are very different from public issues, reaching a smaller set of investors and thus not increasing informed competition as much as a public issue does. This is consistent with earlier work that considers private placements to be closer to syndicated bank loans than to public bonds.

Our next split, (4), is between syndicated and non-syndicated loans: firms whose loan is from a single bank are classified as bank-dependent, while loans from multiple banks are classified as non-dependent. The notion here is that firms that get loans from a single bank are likely to be smaller and face less competitive banking markets. One drawback of this

\footnotetext{
${ }^{4}$ We drop lead banks that do not retain an investment in the loan according to Dealscan or the Share National Credit Program run by the Federal Deposit Insurance Corporation, the Federal Reserve, and the Office of the Comptroller of the Currency.
} 
definition is that, because Dealscan largely focuses on syndicated loans, some publicly-traded firms with single-bank loans may be omitted from the database. More critically, some firms that receive single-bank loans also receive syndicated loans: $2 \%$ of single-loan firms received a syndicated loan at the same time they took out the single-bank loan, and another $14 \%$ had previously received syndicated loans. This makes single-bank loan status a noisy measure of bank-dependence in our sample. ${ }^{5}$

Our final two splits focus more directly on the strength of the lending bank's relationship with the borrower, which is the critical focus of Diamond and Rajan (2000). We look at the borrower's total loan amounts over the previous three years and calculate the percentage that came from the current lead bank. In split (5), the firm is classified as bank-dependent if the current lead bank made at least $50 \%$ of the firm's total loan amounts over the past three years, and as non-dependent otherwise. In split (6), the firm is classified as bank-dependent if the current bank made at least $75 \%$ of total loan amounts, and non-dependent if the bank made no more than $25 \%$ of total loan amounts. Note that both splits require that we drop loans from the first three years of our sample; also, split (6) omits part of the sample, because we remove loans where the lead bank made more than $25 \%$ but less than $75 \%$ of the borrower's prior loan amounts.

\subsection{Methodology}

Our goal is to investigate how a bank's capital level affects its loan pricing, both directly and in concert with various borrower-specific characteristics. Our baseline analysis makes use of the following loan spread model:

$$
\begin{gathered}
\text { LOAN SPREAD } D_{f, l, b, t}=c+\delta_{1} C A P I T A L_{b, t-1}+\gamma_{1} B B B_{t}+\gamma_{2} L I B O R_{t} \\
+\alpha_{t}+\beta_{b}+\sum_{i=1}^{I} \psi_{i} X_{i, l, t}+\sum_{j=1}^{J} \nu_{j} Y_{j, f, t-1}+\sum_{k=1}^{K} \beta_{k} Z_{k, b, t-1}+\epsilon_{f, t} .
\end{gathered}
$$

LOAN SPREAD $f, l, b, t$ is the spread over LIBOR of loan $l$ of firm $f$ from bank $b$ at issue date $t$. According to Dealscan, our source of loan data, the all-in-drawn spread is a measure of the overall cost of the loan, expressed as a spread over the benchmark London interbank offering

\footnotetext{
${ }^{5}$ We thank Daniel Paravisinni for suggesting this definition of bank dependence, and an anonymous referee for pointing out potential caveats.
} 
rate (LIBOR), because it takes into account both one-time and recurring fees associated with the loan. CAPIT $A L_{b, t-1}$ is the lead lending bank $b$ 's ratio of shareholders equity to total assets in the previous reporting period $t-1$.

$B B B_{t}$ is the spread between BBB- and AAA-rated bond index yields on the issue date of the loan. We include this to help proxy for credit market conditions, and to help rule out spurious correlation between bank capital and loan spreads. In a downturn, bank capital levels tend to be lower as higher credit losses reduce equity, and firms may be relatively riskier in ways that our controls do not fully capture. Thus, there may be a correlation between bank capital and loan spreads that is completely driven by overall credit conditions rather than bank- or borrower-specific behavior. As a further credit market control, we include the LIBOR rate on the issue date, $L I B O R_{t}$, since this proxies for banks' general level of cost of funds.

The variables $\alpha_{t}$ and $\beta_{b}$ are year-quarter and bank fixed effects, respectively. The yearquarter fixed effects sweep out macroeconomic conditions, whereas the bank fixed effects sweep out unobservable time-independent bank-specific factors. The $X_{i, l, t}$ represent loan-specific variables, and the $Y_{j, f, t-1}$ represent various firm-specific variables, both of which might be expected to affect the loan's credit risk. The $Z_{k, b, t-1}$ represent various bank-specific variables which might affect the rate at which the bank is willing to lend. We focus on the characteristics of the bank that is the lead arranger. Our reasoning is that it is the lead bank that not only negotiates initial loan terms but is charged with enforcing these terms over the life of the loan, so its characteristics (especially its capital level) will directly affect this behavior. Other members of the syndicate are likely more passive, so their characteristics will have a much weaker effect on the loan negotiations.

In what follows, we augment our baseline specification in several ways. First, because the theories discussed in the previous section suggest that the effect of bank capital may vary with borrower cash flow or risk, we add interaction terms between bank capital and borrower cash flow and, later, between bank capital and one of our other measures of borrower risk. (Note that borrower cash flow and our risk proxies are already present in our list of firmspecific controls $\left.Y_{j, f, t-1}\right)$. However, just as with bank capital's direct effect, finding that one or more of these interactions has a significant impact on loan spread might be a sign of spurious correlation: for example, when credit conditions are weak, borrower cash flow or risk may be more important for loan pricing, because firms are more fragile due to negative spillovers 
from other troubled firms. Accordingly, we control for this by including a matching interaction between borrower cash flow or risk and the BBB-AAA spread.

Next, because all three theories argue that banks have more power vis-á-vis bankdependent borrowers, we estimate our augmented model separately on each of our six bankdependent and six non-dependent subsamples. If the theories are correct, the coefficient on bank capital should be larger and more significant for the bank-dependent subsamples than for the non-dependent subsamples, and the same should be true for the coefficient of the interaction between bank capital and borrower cash flow or risk.

Our main measure of cash flow is LINTCOV, which is the log of 1 plus the interest coverage ratio (i.e., earnings before interest, taxes, depreciation, and amortization (EBITDA) divided by interest expense). ${ }^{6}$ We use three proxies for borrower risk: VOL, PDEFAULT, and BET A. VOL is the standard deviation of the firm's daily stock return over the past twelve months. As a robustness test, we replace volatility in the interaction terms with PDEFAULT, which is Bharath and Shumway's (2008) "naive" estimator of the firm's probability of default. This is a rough implementation of Merton's (1974) structural model of corporate bankruptcy. This estimator has the virtue of being easier to calculate than more rigorous implementations, and actually outperforms them in predicting actual default probabilities. As Bharath and Shumway point out, because of its functional form, using this estimate in addition to its main components (stock volatility, market-based leverage, and the return on the firm's stock) has greater explanatory power for default probabilities than what one finds if one uses either it or its components in isolation. Finally, in some tests we replace stock volatility with $B E T A$, which is the stock's beta relative to the S\&P 500 stock index calculated using daily returns over the past two years. The argument here is that because beta measures systematic (undiversifiable) risk, it may do a better job of capturing the loan's contribution to the bank's loan portfolio risk, making it a more appropriate variable to interact with bank capital as a test of bank risk aversion. $^{7}$

\footnotetext{
${ }^{6}$ In earlier versions of this paper, we also measured cash flow with $L E B I T D A / D E B T$, which is the log of 1 plus EBITDA divided by total debt. Results were similar. We use the natural logarithm transform of interest coverage and EBITDA/debt because both ratios are highly skewed by firms with little or no debt. We did not use another common proxy for firm cash flow, EBITDA divided by total assets; what matters for loan pricing is cash flow relative to debt payments rather than cash flow relative to total assets.

${ }^{7}$ Iannotta, Pennacchi and Santos (2018) provide evidence that both loan and bond spreads account for
} 
Our regressions include a number of additional firm-, loan-, and bank-specific controls that may affect a firm's loan spread. The full list and definitions are given in the appendix. The firm-specific controls include standard variables such as firm size, age, leverage, profitability, asset tangibility, and market-to-book ratio, along with the risk and cash flow variables already mentioned. We also include dummies for different credit rating levels and for single digit SIC codes. The loan-specific controls include loan maturity, amount, and number of lead arrangers in the syndicate, along with indicators for senior status, secured status, presence of dividend restrictions, presence of a guarantor, loan purpose, and loan type. Finally, the bank-specific controls include bank size, profitability, risk, liquid asset holdings and subordinated debt (both scaled by assets), and credit rating, along with the capital/assets ratio already mentioned.

\subsection{Sample characterization}

Table 1 presents the characteristics of our sample, which consists of 15,985 loans taken out by 4,037 nonfinancial borrowers from 301 banks. We begin with the firm controls. As is common in corporate samples, the age, size, market/book ratio, and net working capital/debt are positively skewed, with mean values much greater than median values. As an example, the median firm has sales of $\$ 760$ million, whereas mean sales are $\$ 3,783$ million. By contrast, profit margin is negatively skewed, with a median of $3.70 \%$ and a mean of $0.3 \%$. Other variables are less skewed: for example, leverage has a median (mean) of $29.3 \%$ (30.6\%), the log of interest coverage has a median (mean) of 1.92 (2.04), and tangible assets as a fraction of total assets has a median (mean) of $70.3 \%(71.9 \%)$.

Turning to the loan controls, loan amount is positively skewed, with a median of $\$ 120$ million and a mean of $\$ 324$ million. The median maturity is 3.5 years. Large numbers of loans are secured, senior, or have dividend restrictions, but the percentage with guarantors is small (5.4\%). $22.2 \%$ of loans are term loans, and $58.8 \%$ are credit lines. Lastly, the median number of lead arrangers is 1 , and the mean is only slightly higher (1.17).

Among our bank controls, the mean and median bank capital ratio are $7.42 \%$ and $7.48 \%$, respectively, and the interquartile range is $2.22 \%$. Banks in our sample are quite large: median bank assets are $\$ 210$ billion, and mean bank assets are $\$ 340$ billion. Return on assets has a median of $1.41 \%$ and a mean of $1.31 \%$. By contrast, the bank risk variables (net charge

borrowers' systematic risk. 
offs, return on asset volatility, and Z-score) are all highly positively skewed, indicating that most banks have relatively low risk but a few have very high risk. Less than $2 \%$ of banks have subordinated debt outstanding. Average liquidity ratios are roughly 21\%. Finally, the median LIBOR rate is $5.13 \%$ and the median BBB yield spread is $0.84 \%$.

Table 2 presents summary statistics by subsample for the key variables in our hypotheses tests. Among the bank-dependent subsamples, the most restrictive are (4) and (6)-loans from a single bank and loans where the lead bank accounted for at least $75 \%$ of the borrower's loan amounts in the past three years. This is as one would expect, since the typical Dealscan loan is supposed to be syndicated with a large borrower that is not particularly locked in to one bank. By contrast, a majority of the loans are to unrated borrowers; even more borrowers have not issued a public bond in the last three years or do not have a commercial paper rating. This suggests that Subsamples (4), (5), and (6) are likely the most bank-dependent, with (5) being less bank-dependent than (6).

Recall also that Diamond and Rajan (2000) assume that the basis of the lending bank's advantage over other banks is borrower-specific liquidation skills gleaned from greater experience with that borrower. Having a large share of the borrower's previous loans is the closest proxy for this. Moreover, such a large share is also consistent with other notions of bankdependence, such as the lending bank having generally more precise information about the borrower or having more bargaining power simply because it controls so much of the borrower's funding. These arguments reinforce the notion that Subsamples (5) and (6) are likely to be the most bank-dependent.

Conversely, among our non-dependent subsamples, Subsample (1)—firms with a commercial paper rating - is most restrictive. Such firms are likely to be the least bank-dependent for several reasons: they have an active alternative to bank loans for their short-term financing needs; they must be relatively safe, since commercial paper investors are dominated by money market funds with low risk tolerance; and they are generally a subset of those firms with credit ratings. All of this suggests that their banks' private information should be least significant among all our subsamples. This should hold to a lesser extent for firms that have issued public debt in the last three years (Subsample (3)), since their ability to access the market suggests a reasonable degree of investor comfort, particularly in comparison to the broader set (2) of firms that simply have a credit rating. At the other extreme, firms that borrow from a syndicate 
(Subsample (4)) or whose lead bank made less than $50 \%$ or no more than $25 \%$ of their loan amounts in the previous three years (Subsamples (5) and (6)) may not be quite as independent of banks, since they may not have access to public debt markets. Indeed, although Subsamples (5) and (6) are likely to include many firms with multiple bank relationships, some may have relationships with only two or three banks, while others may have recently switched to a new relationship bank. In short, having less than a certain percentage of one's loans come from the current lead bank is not as clear a signal of non-dependence as having access to public debt markets.

\section{Results}

In this section we present our main results. After estimating the baseline model on the entire sample, we add the interaction of bank capital with borrower cash flow. Next, we re-estimate this augmented model on the twelve bank-dependent and non-dependent subsamples just described. We then add the interaction of bank capital with other borrower risk proxies to see whether the results using cash flow are proxying for other forms of borrower risk.

\subsection{Baseline loan spread determinants}

We begin by estimating three variants of our baseline specification of the relationship between bank capital and loan spreads, Equation (1), on our entire sample. The results of these estimations are given in Table 3. Model 1 includes all of the firm- and bank-specific controls already mentioned, along with industry dummies and year-quarter fixed effects. Model 2 adds the loan-specific controls, and Model 3 adds bank fixed effects. Note that, throughout our analysis, we estimate robust standard errors clustered by firm and by bank.

Given that we will be interested in the impact of bank capital and its interactions with borrower cash flow and risk, several results stand out in all three models. First, bank capital has a significant negative impact on loan spreads, with a reduction of roughly 3 basis points for every percentage point increase in the bank capital-to-assets ratio. Second, borrower interest coverage has a significant negative direct impact on spreads. The addition of loan controls decreases this somewhat, but even in Model 3, a one standard deviation increase in cash flow would decrease loan spreads by almost 15 basis points. Third, both stock volatility and estimated default probability have significant positive direct effects on spreads. The coefficient 
on borrower stock volatility drops roughly $30 \%$ when loan-specific controls are added, and drops $8 \%$ further when bank fixed effects are added; however, the coefficient on estimated default probability actually increases from Model 1 to Model 3. Nevertheless, both remain highly statistically and economically significant: using Model 3's estimates, a one standard deviation increase in volatility (default probability) would increase loan spread by 19 (14) basis points. Consistent with Bharath and Shumway (2008), estimated default probability is significant even when its components such as volatility and leverage are included. Although the borrower cash flow and risk results are what one would expect from any risk-based loan pricing model, the bank capital effect is not predicted by basic loan pricing.

The effects of other firm controls on loan spreads are generally consistent with those found in Santos and Winton (2008) and Hale and Santos (2009). For example, older and larger firms have lower spreads, as do firms with more tangible assets or high recent excess stock returns. Firms with higher leverage have higher spreads. Higher-rated firms pay lower spreads, and vice versa; the exception is the CC-rating dummy, which has a large negative impact on spreads. Given that only $0.3 \%$ of the sample is rated CC, this may reflect an outlier. Again, although the addition of loan-specific controls and bank fixed effects reduces many of the significant coefficients, almost all remain highly significant in all three models. By contrast, the bank controls other than capital generally lose their significance once we include loan-specific controls and bank fixed effects.

Among the loan controls, larger loans do seem to be safer loans. Other loan features seem to proxy for firm risk, as expected from the earlier literature: longer-term loans go to safer firms, whereas secured loans or loans with guarantors tend to go to riskier firms. All of these results are essentially unchanged when we add bank fixed effects.

Finally, we consider our two controls for overall financial conditions. Neither the LIBOR rate nor the BBB yield spread is significant in any of the specifications in Table 3 once we control for year-quarter fixed effects.

In what follows, we will report results for firm interest coverage, firm stock return volatility, firm default probability, and bank capital, because these and their interactions are our main focus. We will also report results for the BBB spread along with any of its interactions. To save space, we will usually omit the results for the other firm-, loan-, and bank-specific controls. 


\subsection{Bank capital and borrower cash flow}

Table 4 presents our first refinement of the baseline model, Equation (1). Inspired by Diamond and Rajan (2000), we add two interaction terms: that between bank capital and borrower cash flow, and that between the BBB spread and borrower cash flow.

The first two specifications in Table 4 correspond to Models (2) and (3) in Table 3: in Model (1), we include all bank, firm, and loan controls as well as industry and year-quarter fixed effects; in Model (2), we add bank fixed effects. In both specifications, the coefficient on bank capital more than doubles. The coefficient on borrower cash flow also increases, though not quite as much in relative terms. Finally, and most importantly, the coefficient on the interaction of bank capital and borrower cash flow is strongly positive and significant, at roughly 1.7 without bank fixed effects and 2.0 with bank fixed effects. This is consistent with lower bank capital increasing spreads for borrowers with low cash flow but having a lesser or even positive effect on borrowers with high cash flow.

Turning to our other key variables of interest, the coefficients on the borrower's stock return volatility and estimated probability of default are positive and significant, with magnitudes similar to those in Table 3. The BBB spread has a positive and, in Model (2), significant effect on rates. The interaction between this spread and borrower cash flow is always negative and significant, which suggests that the beneficial effect of higher cash flow on loan spreads is magnified when credit conditions are tighter.

Because our list of bank controls may omit some critical but unobservable bank characteristics that vary over time, Model (3) of Table 4 replaces bank controls with bank-year-quarter fixed effects. While we can no longer see the direct impact of bank capital (it is subsumed in the fixed effects), the coefficients on borrower cash flow and its interaction with bank capital are virtually unchanged. The coefficients on volatility and probability of default are also unchanged, and the coefficients of the BBB spread and its interaction with cash flow remain significant and actually increase in magnitude. Finally, because many of our firm- and loanlevel controls may be endogenous, in Model (4) we replace them with firm fixed effects while keeping the bank-year-quarter fixed effects of Model (3). Once again, the coefficients of borrower cash flow and its interaction with bank capital retain their signs and significance, albeit with a slight drop in magnitude.

The results in Table 4 suggest that the interaction between bank capital and borrower 
cash flow has a significant effect on loan spreads, modifying the direct effects of capital and cash flow. While this is consistent with the predictions of Diamond and Rajan (2000), other factors could be at work; for example, borrower cash flow may just be an inverse proxy for borrower default risk rather than a measure of borrower liquidity per se. To get further insights, we extend our analysis in two ways: first, seeing whether the capital-cash flow interaction is stronger for borrowers that are more bank-dependent, and second, introducing interactions between bank capital and other measures of borrower risk.

\subsection{Bank capital, borrower cash flow, and borrower bank-dependence}

Our next step is to divide our sample between loans to bank-dependent firms and loans to non-dependent firms, using the six definitions of bank dependence that we discussed in the previous section. We then rerun the regression specification used in Model (2) of Table 4 on each of the six bank-dependent subsamples and on each of the six non-dependent subsamples. Note that, because we include bank fixed effects in all these specifications, coefficients on bank capital and its interactions represent the impact of an increase in capital (or capital times the other variable) relative to the mean sample value for a given bank. Thus, when we refer to high-capital or low-capital banks, this means a bank whose capital is high or low relative to its long-run mean.

Panel A of Table 5 reports the results for the six bank-dependent subsamples listed in Section 3.2. For all six subsamples, the direct impacts of bank capital and of borrower cash flow are negative, highly significant, and somewhat larger in magnitude than in Table 4 . The increase in magnitude is greatest for Subsamples (5) and (6), which we argue are two of our three most bank-dependent subsamples. Most critically, the impact of the interaction between bank capital and borrower cash flow is positive, highly significant, and larger in magnitude than in Table 4, with the greatest increase for Subsamples (5) and (6).

These findings suggest that, although lower bank capital is associated with higher loan spreads for bank-dependent borrowers, the effect is larger for borrowers with lower cash flow and vice versa. To get a better sense of these effects, we present two additional pieces of evidence. First, we test to see whether the combined effect of bank capital and its interaction with borrower cash flow is significantly different from zero both at the subsample means of these variables and when cash flow is one standard deviation above or below this mean. At 
the bottom of Panel A, we report p-values for the hypothesis that this effect is not different from zero. (In the hypothesis statements, $\delta_{1}$ is the direct coefficient on bank capital and $\delta_{2}$ is the coefficient on capital's interaction with borrower cash flow.)

When borrower cash flow is one standard deviation below its subsample mean, we strongly reject this null hypothesis: p-values are 0.0003 or lower in all subsamples. Even when borrower cash flow is at its mean, the null is rejected, with p-values generally 0.01 or lower (except for Subsample (2), where the p-value is just above 0.01, and Subsample (5), where it is just above 0.05.) However, when borrower cash flow is one standard deviation above its mean, we cannot reject the null. It follows that bank capital's impact on loan spreads is significantly negative for low and medium cash-flow borrowers, but insignificantly negative for high cash-flow borrowers.

As a second test, we investigate the economic magnitudes of the effects of bank capital on loans spreads. To that end, we present in Table 6 a matrix of the total spread effects of different combinations of bank capital and borrower cash flow levels for Subsample (1) and Subsample (6). For Subsample (1), when borrower cash flow is one standard deviation below its mean, a two-standard deviation increase in bank capital (from one standard deviation below to one above the mean) causes loan spreads to decline 20 basis points; when borrower cash flow is at its mean, the same increase in capital causes loan spreads to decline 11 basis points; and when borrower cash flow is one standard deviation above its mean, the same increase in bank capital causes spreads to decline only 2 basis points. For Subsample (6), the corresponding effects of a two standard deviation increase in bank capital are declines of 21 basis points, 13 basis points, and 4 basis points (for borrower cash flow one standard below the mean, at the mean, and one standard deviation above the mean, respectively). ${ }^{8}$ Given that the mean loan spread in our sample is 177 basis points, this suggests that the effect of bank capital on spreads for low and medium cash-flow borrowers is not only statistically significant but economically significant as well.

We now turn to Panel B of Table 5, which report the equivalent regressions for our six non-dependent subsamples. The patterns here for the coefficients of bank capital, borrower cash flow, and their interaction are the reverse of those in Panel A. In all cases, the coefficients are smaller and less significant than in the full-sample results of Model (2) in Table 4. For

\footnotetext{
${ }^{8}$ Results for our other subsamples are similar and are available on request.
} 
Subsample (1), the coefficients of these three terms are not only insignificant but have the opposite sign from Table 4; for Subsamples (2) through (4), the coefficients' signs are generally the same as in Table 4 but insignificant; finally, for Subsamples (5) and (6) the signs are as in Table 4 and the coefficients are significant, although only marginally so for the interaction term. As noted previously, non-dependent Subsamples (1) through (3) are probably the least bank-dependent (especially Subsample (1)), so these findings are consistent with bank capital and borrower cash flow having their greatest impact on loan pricing for bank-dependent firms.

As in Panel A, we also report p-values testing whether the combined effect of bank capital and its interaction with borrower cash flow is statistically different from zero. This null hypothesis is only rejected for low and medium cash-flow borrowers in Subsamples (5) and (6); for all other subsamples and borrower cash flow levels, the null cannot be rejected. Finally, Table 6, Panel B gives a sense of the economic magnitude of these effects for Subsamples (1) and (6). In the case of Subsample (1) (firms with commercial paper ratings), the impact on loan spreads of a two-standard deviation increase in bank capital is positive but small (no more than 4 basis points in absolute value). In the case of Subsample (6), a two standard deviation increase in bank capital decreases spreads by 15 basis points, 9 basis points, and 3 basis points (for borrower cash flow one standard below the mean, at the mean, and one standard deviation above the mean, respectively), or roughly $25 \%$ less than the equivalent changes for bank-dependent Subsample (6).

Note that, for all bank-dependent and non-dependent subsamples, our borrower risk variables (stock return volatility and estimated default probability) all have the same signs as in our baseline regressions and are strongly significant. The estimated coefficients for the risk variables tend to be somewhat smaller in the bank-dependent subsamples than in the overall sample or the non-dependent subsamples, with the biggest coefficients occurring in the first three non-dependent subsamples. Because these three subsamples correspond to having access to public debt markets, this may reflect that when public information about firms is more pervasive, stock prices and the risk measures based on them (volatility and estimated default probability) are more accurate. In addition, though cash flow is often insignificant for the most non-dependent subsamples, the interaction of cash flow and the BBB spread is always negative and usually significant for all of the bank-dependent and non-dependent subsamples. Indeed, it is strongest for the least dependent subsamples (borrowers with commercial paper ratings or 
credit ratings), suggesting that cash flow effects become critical even for the least dependent borrowers when credit conditions are tight.

Summing up, for our bank-dependent subsamples we find that the interaction between borrower cash flow and bank capital has a highly significant impact on loan spreads. For borrowers with low cash flows, the effect is quite large - almost double that for borrowers with cash flows at the mean; by contrast, it is insignificant for borrowers with cash flows one standard deviation above the mean. Although this is consistent with Diamond and Rajan's prediction that low-capital banks have more bargaining power than high-capital banks do vis-á-vis lowcash flow borrowers, it may be that borrower cash flow is acting as a proxy for borrower risk. In our next subsection, we look at the impact of borrower risk in more detail.

\subsection{Bank capital and borrower risk}

As just noted, it is possible that the significant interaction between bank capital and borrower cash flow reflects increased general risk aversion by low-capital banks rather than the liquiditydriven bargaining power story of Diamond and Rajan (2000). To investigate this, we augment the regression specifications of the preceding subsection with interactions between bank capital and various proxies for borrower risk. We also add the interaction between the BBB spread and the borrower risk proxy; once again, this is to rule out spurious correlation where borrower risk matters more during credit downturns.

Our first proxy for borrower risk is the volatility of the borrower's stock return over the previous year. We present the results in Table 7, where again Panel A contains results for the bank-dependent subsamples and Panel B contains the results for the non-dependent subsamples.

Beginning with bank-dependent firms in Panel A, we see that the direct impact of bank capital, while still negative, is now smaller and less significant for Subsamples (1) and (2) and insignificant for Subsamples (3) and (4). Nevertheless, it remains significantly and strongly negative for our most bank-dependent subsamples, Subsamples (5) and (6); in fact, the coefficient for Subsample (6) is actually somewhat larger than the matching coefficient in Table 5. The direct impact of borrower cash flow is also somewhat smaller than in Table 5, but it remains significantly negative and is largest for Subsamples (5) and (6). The interaction between bank capital and borrower cash flow remains positive and significant in all subsamples 
(though weakly in Subsample (3) and Subsample (4)); for Subsamples (5) and (6), it is not only highly significant but little changed from Table 5 . As in Table 5, the interaction of the BBB spread and borrower cash flow is negative and significant in most specifications

The results for borrower stock return volatility are less striking. Although the direct impact of volatility is positive, significant, and larger than in Table 5, its interaction with the $\mathrm{BBB}$ spread is actually negative, which is the opposite of what one would expect if spurious correlation were important for the results. Most critically, the interaction of volatility and bank capital is small and never statistically significant.

Next, we formally test for whether the combined effects of bank capital and its interactions with borrower volatility and cash flow are significantly different from zero. (In these tests, $\delta_{1}$ and $\delta_{2}$ are as before, and $\delta_{3}$ is the coefficient on the interaction between bank capital and borrower volatility.) Again, we hold bank capital and borrower volatility at their subsample mean values and do tests at three levels of borrower cash flow: one standard deviation below cash flow's subsample mean, at this mean, and one standard deviation above this mean. The results are very similar to those from Table 5: when borrower cash flow is below its mean, the null is soundly rejected, with p-values of 0.0027 or less; when borrower cash flow is at its mean, the null is again rejected, but with p-values well above 0.01 in the cases of Subsample (2) and Subsample (5); and when borrower cash flow is above its mean, the null is never rejected, with p-values of 0.3190 or more.

The results for non-dependent firms in Table 7, Panel B, show a number of differences from those in the Table 5 regressions. The direct effect of bank capital remains negative for Subsamples (5) and (6), but smaller and insignificant now; by contrast, this effect is now marginally significant for Subsamples (2) and (4). The direct effect of cash flow remains negative in most subsamples, but with only marginal significance at best, while the interaction between capital and cash flow is no longer significant even for Subsamples (5) and (6). The direct effect of volatility remains positive, but it loses significance in Subsamples (1) through (4). Critically, the interaction between volatility and bank capital is significant only in Subsample (4), and in that case has a positive sign, the opposite of what bank risk aversion would predict.

As before, we formally test for whether the combined effect of bank capital and its interactions is significantly different from zero. Just as in Table 5, the null hypothesis is only 
rejected for low and medium cash-flow borrowers in Subsamples (5) and (6), but the p-values are now much larger, with several only significant at the 0.05 level and one only at the 0.10 level.

One possible objection to stock volatility as a measure of the interaction of borrower risk with bank capital is that volatility reflects both upside and downside equity risk, whereas banks should be largely concerned with borrower's downside risk, and especially with the borrower's risk of actual default. Accordingly, as a robustness test, we use interactions of bank capital and of the BBB spread with the borrower's estimated default probability rather than with its stock return volatility. These results can be found in Table IA.1 in the internet appendix, with bank-dependent subsamples in Panel A and non-dependent subsamples in Panel B.

For bank-dependent firms, the magnitude and significance of coefficients for bank capital, borrower cash flow, and their interaction are largely the same as in Table 5, though the size and significance are now somewhat lower for Subsamples (5) and (6). However, even though the direct impact of default probability remains positive and significant, its interaction with bank capital is never significant, although it is negative in most subsamples. As in Table 5, tests of the null hypothesis that the combined impact of bank capital is not different from zero are rejected both for low and for medium cash-flow borrowers (with similar p-values as in the earlier table), but not for high cash-flow borrowers.

When we turn to the results for non-dependent firms in Table IA.1, Panel B, we see that bank capital, borrower cash flow, and their interaction have similar patterns of coefficients as those found in Table 5, Panel B. However, default probability and its interaction with bank capital are generally insignificant, whereas in Table 5 default probability was always positive and highly significant. As in Table 5, hypothesis tests for the combined effect of bank capital and its interactions reject the null for low and medium cash flow borrowers in Subsamples (5) and (6) and do not reject it for high cash-flow borrowers or for any borrower cash flow levels in the other four subsamples.

Although these results are broadly similar to those using borrower stock volatility (Table 7), a big caveat is in order. Estimated default probability is highly skewed: from Table 1, its median is zero, and the third quartile is only 0.001 , but its mean is 0.0468 and its standard deviation is 0.1541 . As a result, the interaction of bank capital and default probability is highly correlated with both default probability itself and with the interaction of the BBB 
spread and default probability. ${ }^{9}$ Not only does this multicolinearity make it hard to interpret the coefficients on default probability and its interactions, but these interactions add little to the span of the independent variables, and so the coefficients of other variables such as bank capital and borrower cash flow are basically unchanged.

\subsection{Bank capital and systematic borrower risk}

As a final extension, we examine how substituting borrower equity betas for stock volatility (and for its interaction with bank capital and BBB spread) affects our results. Our motivation comes out of Froot and Stein (1998): to the extent borrower risk on illiquid loans matters more to banks with low capital, it should be the portion of this risk that is not diversifiable that matters most. ${ }^{10}$ Beta is a simple proxy for this risk. Table 8 shows our results using betas calculated from daily returns over the past two years.

We begin with Panel A, which has the results for the bank-dependent subsamples. Compared with the matching results in Table 5, the coefficient for bank capital is still negative and significant, though slightly smaller; the coefficients for borrower cash flow and its interaction with bank capital are almost unchanged in size and significance. The coefficient for borrower beta is positive and significant in every case except Subsample (4), and is especially significant and large for Subsamples (5) and (6). More important, the coefficient for the interaction between bank capital and borrower beta is negative and significant at the $5 \%$ level in all subsamples except Subsample (4), where it is not significant, and Subsample (6), where it is significant at the $10 \%$ level. Thus, in contrast to our results for borrower stock volatility and estimated default probability, there is some evidence that banks with lower capital charge a higher premium on borrowers' systematic risk than do banks with higher capital. In economic terms, increasing bank capital by two standard deviations (roughly 3 percentage points) only decreases the sensitivity of the loan spread to beta by 7.5 to 14.0 basis points per unit of beta, depending on the subsample. Since a two-standard deviation change in beta is roughly 0.70 to 0.80 for these subsamples, a two-standard-deviation increase in beta would increase loan

\footnotetext{
${ }^{9}$ The correlation between default probability and its interaction with bank capital is 0.976 ; that between default probability and its interaction with the BBB spread is 0.924 ; and that between the interactions of default probability with bank capital and with the BBB spread is 0.909.

${ }^{10}$ We thank one of our referees for raising this point.
} 
spreads for a low-capital bank by only 5.6 to 10.5 basis points more than for a high-capital bank.

Turning back to the combined impact of bank capital and its interactions, which is our main focus, we conduct the same hypothesis tests as before for mean levels of bank capital and borrower beta and for borrower cash flows one standard deviation below the mean, at the mean, and one standard deviation above the mean. As in Table 5, we reject the null of zero impact for both low cash-flow and medium cash-flow borrowers, but not for the high cash-flow borrowers.

Panel B of Table 8 gives the results for non-dependent borrowers. As in our earlier results, the coefficients of bank capital and its interaction with borrower cash flow are insignificant for Subsamples (1) through (4). The same is true for the coefficients of borrower beta and its interaction with bank capital. For Subsamples (5) and (6), there is marginal significance for the positive impact of the interaction of capital and cash flow, and stronger significance for the impact of beta (positive) and the impact of its interaction with capital (negative).

Some caveats are in order. First, we have measured beta relative to the S\&P 500 stock index. Although this is a common benchmark portfolio, most bank borrowers are not in it, and so our beta measures may be a less accurate measure of borrower equity risk than those based on a more all-encompassing market portfolio. More critically, what should matter for bank portfolio risk is the covariance of the borrower's debt's risk with that of the bank's overall portfolio, which is something we do not possess. Indeed, as Carey (1998) has shown, because of the heavily left-skewed returns of debt instruments, debt portfolio risk does not diversify away idiosyncratic risk as quickly as equity portfolios do, making borrower beta a less accurate measure of the borrower's contribution to the bank's portfolio risk. Third, using daily returns to measure beta risks spurious effects due to bid-ask bounce rather than true price movements.

To deal with this last concern, we also calculated betas using weekly and monthly returns over the previous two years and then reran the regressions from Table 8. The results are in Table IA.2. Panels A1 and A2 present weekly-beta results for bank-dependent and nondependent borrowers, respectively, whereas Panels B.1 and B.2 show the monthly-beta results. Using weekly betas, the direct impact of beta is much smaller now; for the bank-dependent borrowers, it is always positive but only significant (marginally) in subsamples (5) and (6), and it is never significant and has varying sign for the non-dependent borrowers. The interaction 
term is generally insignificant, though it usually has the right sign for the bank-dependent borrowers.

Results using monthly betas fall between those using daily and weekly returns. Beta's direct impact for bank-dependent borrowers is always positive but marginally significant at best, while it is generally insignificant for non-dependent borrowers. For bank-dependent borrowers, the interaction term is always negative and often marginally significant, while it is negative and marginally significant for non-dependent Subsamples (5) and (6).

\subsection{Summary}

Our results in this section show that bank-dependent borrowers pay higher spreads on their loans when their lead bank's capital is low relative to its mean, and vice versa. The effect is present for borrowers with cash flows at the sample mean, and is even stronger for borrowers whose cash flows are below the mean; by contrast, there is no evidence of this effect when borrowers have cash flows one standard deviation or more above the mean. These effects are generally strongest for firms that are likely to be more dependent on (that is, have a stronger relationship with) their current lead bank-Subsamples (5) and (6) in our bank-dependent specifications.

By contrast, among firms classified as non-dependent, those with access to public debt markets show almost no evidence of these effects. When we modify the definition of "nondependent" to mean firms that have weaker relationships with their current lead bank, there is some evidence of this premium charged by low-capital banks to low-cash-flow borrowers, but the effects are typically weaker than for our bank-dependent subsamples.

Because we include a proxy for credit conditions (the BBB spread) and its interaction with borrower cash flow as controls, the results we have just described are unlikely to be driven by spurious correlation between bank capital and borrower cash flow when credit spreads are high and vice versa. Moreover, they do not seem to be driven by borrower cash flow serving as a proxy for borrower credit risk per se, since the cash flow results are largely robust to including interactions between various borrower risk proxies (stock return volatility, estimated default probability, and equity beta), bank capital, and credit conditions. The fact that estimated default probability and its interactions have almost no impact on our cash flow results is especially revealing, since this risk measure explicitly focuses on default risk rather than equity 
risk. Nor is it the case that borrower cash flow simply proxies for default probability; while the two are negatively correlated, the correlation coefficient is only -0.31 . Thus, it seems most likely that borrower cash flow proxies for a form of liquidity risk along the lines of Diamond and Rajan (2000) rather than pure credit risk.

By contrast, our results show only weak support for the bank risk-aversion theory of Froot and Stein (1998): the interactions of borrower risk proxies with bank capital are themselves insignificant, with the exception of borrower equity beta. For beta, we find some evidence that low-capital banks charge bank-dependent borrowers a higher premium per unit of beta risk than high-capital banks do, but the strength of the effect varies with whether beta is measured from daily, weekly, or monthly returns, and even in the case of daily returns, the economic magnitude of the effect is smaller than that of the cash flow effect. As noted earlier, however, our beta measures have limitations as proxies for the covariance between a loan and the bank's overall portfolio.

\section{$5 \quad$ Ruling Out Selection and Endogeneity}

Although our results thus far show that banks with capital lower than their long-run mean charge higher loan spreads, and that this is mitigated for borrowers with high cash flows, causality remains an issue. We have ruled out spurious correlation caused by overall credit conditions, but it is still possible that our result is driven by selection of low-capital banks towards riskier borrowers, or riskier borrowers towards low-capital banks. Similarly, while we employ a large number of controls, many of our firm-level and loan-level controls are likely to be endogenous. In this section, we address these two alternatives.

\subsection{Firm-bank selection effects}

As just noted, our results might be driven by selection, where banks with lower capital either seek out or attract unobservably riskier borrowers. Alternatively, banks with lower capital may be those that have taken on unobservably riskier borrowers and suffered losses as a result.

Standard risk-shifting arguments suggest that, counter to Froot and Stein's (1998) bank risk-aversion model, low-capital banks should seek out riskier borrowers, whether or not the 
risk is observable. ${ }^{11}$ To the extent risk-shifting is a motivation for selection, we ought to find evidence for it in terms of the observable risk of the loans that low-capital banks hold. As a test for this, we conduct a two-step procedure. In the first stage, we rerun our three regressions from Table 3-loan spread regressed first on firm- and bank-specific controls, then on loanspecific controls as well, and finally with bank fixed effects - but leaving out bank capital as a regressor. The results of this regression are shown in Table IA.3 in our Internet Appendix. In the second stage, for each loan observation, we calculate the predicted loan spread based on the first-stage regressions, and then regress this predicted spread on the lead bank's capital ratio. The results of the second stage are shown in Table 9. As can be seen, bank capital is highly significant in all three models, but strongly positive, with a coefficient of between 11.5 and 11.6 basis points per percentage point of capital, and an R-squared of 0.11 to 0.13 . To the extent that higher spreads reflect higher risk, this suggests that banks with higher capital take on more risk, not less. This is consistent with Froot and Stein (1998) and the opposite of what the risk-shifting model predicts.

Although one might argue that risk-taking banks focus on unobservable risk because regulators can take action against observable risk, our analysis in previous sections weighs against this on several grounds. First of all, by using bank fixed effects, we rule out any selection linked to a bank's time-invariant characteristics, including its average capital ratio. Second, because the direct effects of bank capital are largely confined to bank-dependent borrowers, a selection story would have to be confined to such firms. Moreover, because our results are greatest for firms whose current lead bank accounted for at least $75 \%$ of their total loan amounts over the previous three years, this story would have to be most salient for such borrowers. Although such borrowers may be more opaque, it is not clear why low-capital banks would deliberately seek out those firms among them that are observably safer but unobservably riskier. Indeed, given high-capital banks' greater apparent tolerance for risk, one would think the high-capital banks would seek out such borrowers. It is also hard to see why riskier opaque borrowers would seek out low-capital banks, since theory and evidence suggest that such firms try to avoid relying on weaker banks (see Detragiache, Garella, and Guiso (2000).)

Third, and most critically, our results when we include bank capital's interactions with borrower cash flow and risk are hard to square with selection. To be consistent with

\footnotetext{
${ }^{11}$ See for example Merton (1978).
} 
these results, unobservably riskier borrowers with low cash flows would have to go to lowcapital banks, but unobservably riskier borrowers with high cash flows would have to either not select low-capital banks or actually select high-capital banks if their cash flows were especially high. By contrast, other aspects of borrower risk such as stock volatility, estimated default probability, and to some extent equity beta would have to have little or no effect on selection. It is hard to think of a single selection model that links all these results.

As a further test, we add bank-year-quarter fixed effects to our regressions, so as to capture any unobservable variation in a given bank's profile or preferences that affects which borrowers that it seeks or attracts. Indeed, we already performed this test on the full sample of loans in Model (3) of Table 4. Although in principle we could make this change to the specifications used in Tables 5, 7, and 8, in practice the subsamples associated with these regressions are too small to allow for so many fixed effects while producing strongly significant results. Instead, we run regressions on the entire sample of loans while using an indicator variable for whether a borrower is considered non-dependent. We have six specifications, corresponding to each of our bank-dependence measures. We then run regressions for all the controls used previously, along with the indicator variable and its interactions with key variables. Effectively, this allows us to specify "different" regression coefficients for bank-dependent and non-dependent borrowers while keeping the larger combined sample for estimating bank-year-quarter fixed effects. Our results are presented in Table 10 and Tables IA.4 and IA.5 of the Internet Appendix. (These tables correspond to Tables 5, 7 and 8, respectively, in terms of the key variables and interactions that are used.)

Comparing these tables, it is immediately clear that cash flow and its interaction with bank capital have coefficients and significance that are strong and similar to those in the splitsample tables (Tables 5, 7, etc.). When these terms are interacted with the non-dependent indicator $(N O N D E P)$, however, the new terms' sign usually flips and is often statistically and economically significant, reducing much of the impact observed for bank-dependent firms. We find similar effects for bank capital: while we do not observe a direct impact of capital on bank-dependent firms (this is subsumed in the bank-year-quarter fixed effects), the interaction of bank capital with the non-dependent indicator is often positive and highly significant. This is consistent with capital having less impact on non-dependent firms' loan rates.

By contrast, results for interactions with firm stock return volatility (Table IA.) are 
inconsistent. Volatility sometimes has greater impact for non-dependent firms than for bankdependent firms, and the impact of its interaction with capital is often negative, rather than positive as Froot and Stein (1998) would suggest. Results for beta (Tables IA.5) are similar to, but somewhat weaker than, the results from our split sample specifications.

The evidence from these robustness tests suggests that the capital-cash flow interaction found earlier is not due to unobservable variation in bank characteristics over time. More generally, the evidence we have is not consistent with a simple selection story in which low-capital banks attract riskier borrowers. High-capital banks seek out (observably) riskier borrowers, and low-capital banks charge low and medium cash-flow borrowers who are bank-dependent higher spreads than high-capital banks do.

\subsection{Endogeneity of control variables}

A further concern with our regressions is that many of our controls are closely related to one another. Not only are non-price loan terms jointly determined with spread, but default probability, interest coverage, leverage, and stock return volatility are interrelated. Although the coefficients of most controls are relatively stable from specification to specification, endogeneity remains a concern.

We introduce two sets of robustness tests to deal with this. In the first, we rerun the split-sample specifications in Tables 5, 7, and 8, but replace most firm, bank, and loan controls with bank-year-quarter and borrower fixed effects. The only controls that are retained are those that are the main focus of each specification and which are not absorbed by the two sets of fixed effects. For example, Table 11, which corresponds to Table 5, includes only borrower cash flow, its interaction with bank capital, the BBB spread, and its interaction with borrower cash flow; capital's direct effect is subsumed in the bank-year-quarter fixed effect. (In the Internet Appendix, Tables IA.6 and IA.7 do the same refinement to the tests in Tables 7 and 8 , respectively).

The results suggest that our findings on cash flow and capital for bank-dependent borrowers are not driven by correlation among the many controls in our full model. Focusing on our main specification, Panel A of Table 11 shows that, for bank-dependent borrowers, the direct impact of cash flow on loan spread is always negative and economically and statistically significant. Similarly, the interaction of cash flow and capital is always positive, though in the 
case of Subsample (5) it is only marginally significant and in Subsample (6) it is insignificant. Just as in Table 5, the BBB spread continues to have a positive direct effect and a negative interaction with cash flow. By contrast, looking at Panel B of Table 11, non-dependent borrowers show little evidence of these effects: cash flow varies in sign, and is only significant (and negative) in one case, and the interaction of capital and cash flow is significant in only two cases, and in one of these cases (Subsample (6)) it is negative rather than positive.

When interactions with other risk proxies are added (Tables IA.6 and IA.7), the results for cash flow and its interaction with bank capital show similar patterns. Results are little changed for bank-dependent borrowers, though they lose significance in the two most bank-dependent subsamples; for non-dependent borrowers, there is little evidence of significant effects. By contrast, the interaction of volatility and capital (in Table IA.6) and of beta and capital (Table IA.7) are generally insignificant and inconsistent in sign across the various subsamples for both bank-dependent and non-dependent borrowers.

Our second robustness test takes the complete sample/non-dependent indicator variable specifications of Tables 10 and Internet Appendix Tables IA.4 and IA.5, drops all but the focal controls, and adds firm fixed effects to the bank-year-quarter fixed effects already used in those tables. The results are provided in Internet Appendix Tables IA.8, IA.9, and IA.10, respectively and are broadly similar to the earlier tables. For dependent borrowers, cash flow is negative and significant, cash flow's interaction with bank capital is positive and significant, and these are little affected when we include the interaction of capital with volatility or beta. While Subsample (6) sometimes loses significance, overall, the results are much stronger than in the split sample specifications of Table 10 and Internet Appendix Tables IA.4 and IA.5. The interaction of the non-dependent indicator and the three key variables (capital, cash flow, and their interaction) usually has the opposite sign of the direct effect and is often significant. This provides even firmer support for our earlier findings on the impact of cash flow and capital. By contrast, the interaction of volatility or beta with bank capital does not show consistent effects.

In summary, dropping most controls and replacing them with bank-year-quarter and firm fixed effects does not change our main finding: the interaction of bank capital and borrower cash flow has a significant positive impact on loan spreads. While this result is somewhat weaker in Subsamples (5) and (6), this may be due to these subsamples containing relatively 
more firms that show up only once and thus are completely subsumed by the firm fixed effects, and to these subsamples being smaller than the others in the face of a big increase in the total number of fixed effects.

\section{Other Robustness Tests}

In addition to the robustness tests described in the previous section, we examined a number of alternative specifications. We will now discuss these briefly.

Our data includes both term loans and credit lines and we include in all of our regressions a dummy variable to distinguish the type of the loan. Since these loan types are priced differently, as a robustness test we rerun the specifications from Tables 3, 5 and 7 using only credit lines, which are the most common loan type in our sample. The results of this exercise, which are reported in the Internet Appendix Tables IA.11 through IA.13, show that our key findings continue to hold for this subset of loans.

Our analysis relies on the book value of bank's common equity relative to total book assets as our measure of bank capital. While this is consistent with regulators' focus on book capital, bank managers may also be motivated by the market value of bank equity relative to total market value of assets. Accordingly, we have rerun the equivalent specifications from Tables 3, 5 and 7, but with banks' market capital to assets in place of book capital to assets (see Internet Appendix Tables IA.14 through IA.16). Dropping loans whose lead arranger is not publicly traded causes us to lose roughly one third of our observations. In the case of bank-dependent borrowers, we find no significant effects for banks' market equity to assets ratio and its interaction with borrower cash flow or other risk measures, but there is limited evidence for a negative impact of market capital on loan rates for the least bank-dependent firms - those with access to public debt markets. To the extent that market capital differs from book capital by incorporating growth opportunities which are likely to be lost if a bank becomes distressed, depositors and holders of other bank liabilities may well focus on book capital as the more accurate indicator of what is there to protect them against bank failure. Moreover, if the threat of regulatory intervention is what drives low-capital banks' aversion to taking on borrower liquidity or default risk, book capital (which is regulators' key focus) is again the more relevant indicator.

Finally, given that the top three banks - Citigroup, J. P. Morgan Chase, and Bank of 
America - are lead arrangers on $46 \%$ of the loans in our sample, the idiosyncracies of these three may be driving our results. Accordingly, we drop these loans from our sample and rerun our basic tests. Our qualitative findings remained unchanged. We also use the log of $($ EBITDA/Total Debt +1$)$ as an alternative measure of borrower cash flow. Once again, our qualitative results are unchanged.

\section{$7 \quad$ Final remarks}

Our paper examines the link between a bank's capital level and the rates it charges its borrowers, and how this link is affected by the borrower's relative bargaining power. Our results strongly support the predictions of Diamond and Rajan (2000): bank capital's impact depends on the cash flow position of the borrower, with low-cash-flow borrowers having little bargaining power, and high-cash-flow borrowers having greater bargaining power, vis-a-vis low-capital banks. This is also consistent with a modified interpretation of Boot, Greenbaum, and Thakor (1993) in which high cash flow makes a borrower effectively non-dependent on banks. By contrast, we find only weak evidence in favor of banks with lower capital being effectively more risk averse in their pricing of bank-dependent borrowers, as proposed by Froot and Stein (1998).

These results are of more than academic interest, because the estimated impact of bank capital is economically significant. For the most bank-dependent borrowers, those whose lead bank accounted for at least $75 \%$ of their total loan amounts in the previous three years, a drop in bank capital of only 1.6 percentage points (one standard deviation) results in a 6.7 basis point increase in spread for the average borrower and an 11.0 basis point increase for borrowers with cash flows one standard deviation below the mean. Results for borrowers whose lead bank accounted for at least $50 \%$ of previous loans are of similar magnitude - yet these two groups respectively account for $35 \%$ and $43 \%$ of our sample of loans to publicly-held borrowers. Finding that bank capital has significant effects on these borrowers suggests that the effects on privately-held borrowers are likely to be even greater. ${ }^{12}$

\footnotetext{
${ }^{12}$ Again, Schenone's (2010) work suggests that privately-held borrowers are subject to greater bank lock-in effects than publicly-traded borrowers.
} 


\section{References}

Berger, Allen N., and Gregory F. Udell, 1990. "Collateral, Loan Quality, and Bank Risk." Journal of Monetary Economics 25(1), 21-42.

Bharath, Sreedhar T., and Tyler Shumway, 2008. "Forecasting Default with the Merton Distance to Default Model." Review of Financial Studies 21, 1037-1075.

Boot, Arnoud, W.A., Stewart I. Greenbaum, and Anjan V. Thakor, 1993. "Reputation and Discretion in Financial Contracting." American Economic Review 83, 1165-1183.

Cornett, Marcia, Jamie J. McNutt, Philip Strahan, and Hassan Tehranian, 2011. "Liquidity Risk Management and Credit Supply in the Financial Crisis." Journal of Financial Economics 101, 297-312.

Dennis, Steven A., and Donald J. Mullineaux, 2000. "Syndicated Loans." Journal of Financial Intermediation 9, 404-426.

Diamond, Douglas W., and Raghuram G. Rajan, 2000. "A Theory of Bank Capital." Journal of Finance 55(6), 2431-2465.

Froot, Kenneth, and Jeremy Stein, 1998. "Risk Management, Capital Budgeting, and Capital Structure Policy for Financial Institutions: An Integrated Approach." Journal of Financial Economics 47(1), 55-82.

Froot, Kenneth, Jeremy Stein, and David Scharfstein, 1993. "Risk Management: Coordinating Corporate Investment and Financing Policies." Journal of Finance 48(5), 1629-1658.

Detragiache, Enrica, Paolo Garella, and Luigi Guiso, 2000. "Multiple versus Single Banking Relationships: Theory and Evidence." Journal of Finance 55(3), 1133-1161.

Hale, Galina B. and João A.C. Santos, 2009. "Do Banks Price their Informational Monopoly?" Journal of Financial Economics 93, 185-206.

Hubbard, Robert G., Kenneth N. Kuttner, and Darius N. Palia, 2002. "Are there Bank Effects in Borrowers' Costs of Funds? Evidence from a Matched Sample of Borrowers and Banks." Journal of Business 75(4), 559-581.

Iannotta, Giuliano, George Pennacchi, and João A.C. Santos, 2018. "Ratings-Based Regulation and Systematic Risk Incentives." Review of Financial Studies, forthcoming.

Ivashina, Victoria, and David S. Scharfstein, 2010. "Bank Lending during the Financial Crisis of 2008." Journal of Financial Economics 97, 319-338.

Mattes, Julian, Sascha Steffen, and Mark Wahrenburg, 2013. "Do Information Rents in Loan Spreads Persist over the Business Cycles?" Journal of Financial Services Research 43(2), 175-196.

Merton, Robert, 1974. "On the Pricing of Corporate Debt: The Risk Structure of Interest Rates." Journal of Finance 29, 449-470.

Merton, Robert, 1978. "On the Cost of Deposit Insurance When There Are Surveillance Costs." Journal of Business 51, 439-452. 
Petersen, Mitchell A., 2009. "Estimating Standard Errors in Finance Panel Data Sets: Comparing Approaches." Review of Financial Studies 22, 435-480.

Rajan, Raghuram G., 1992. "Insiders and Outsiders: The Choice between Informed and Arm's Length Debt." Journal of Finance 47(4), 1367-1400.

Santos, João A.C., 2011. "Bank Loan Pricing Following the Subprime Crisis." Review of Financial Studies 24, 1916-1943.

Santos, João A.C., and Andrew Winton, 2008. "Bank Loans, Bonds, and Informational Monopolies across the Business Cycle." Journal of Finance 63, 1315-1359.

Schenone, Carol, 2010. "Lending Relationships and Information Rents: Do Banks Exploit Their Information Advantages?" Review of Financial Studies 23(3), 1149-1199.

Sufi, Amir, 2007. "Information Asymmetry and Financing Arrangements: Evidence from Syndicated Loans." Journal of Finance 62(2), 629-668.

Sharpe, Steven A., 1990. "Asymmetric Information, Bank Lending, and Implicit Contracts: A Stylized Model of Customer Relationships." Journal of Finance 45(4), 1069-1087. 


\section{Appendix 1: Definition of variables}

\section{FIRM CONTROLS}

$A A, A A, \ldots C$ : Credit rating of the borrower.

ADVERTISING : Advertising expenses over sales.

$A G E$ : Age of the borrower in years.

$B E T A$ : Stock's beta relative to S\&P 500 based on daily returns over past two years.

$B E T A w$ : Stock's beta relative to S\&P 500 based on weekly returns over past two years.

$B E T A m$ : Stock's beta relative to S\&P 500 based on monthly returns over past two years.

$E X R E T$ : Return on the borrower's stock over the market return.

$L E B I T D A D E B T:$ Log of the ratio between EBITDA and debt truncated at 0.

$L E V E R A G E$ : Debt over assets.

$L I N T C O V:$ Log of interest coverage truncated at 0.

$M K T O B O O K$ : Market to book value.

$N W C$ : Net working capital (current assets less current liabilities) divided by total debt.

$P D E F A U L T$ : Probability of default of the borrower.

PROF MARGIN : Net income over sales.

$R \& D$ : Research and development expenses over sales.

$S A L E S$ : Sales of the borrower in 100 million dollars.

$V O L$ : Standard deviation of the borrower's stock return.

$T A N G I B L E S$ : Share of the borrower's assets in tangibles.

\section{LOAN CONTROLS}

AMOUNT : Loan amount in 100 million dollars.

CORPURPOSES : Dummy variable equal to 1 if the loan is for corporate purposes.

$C R E D I T L I N E$ : Dummy variable equal to 1 for lines of credit.

$D E B T$ REPAY : Dummy variable equal to 1 if the loan is to repay existing debt.

$D I V I D E N D$ REST : Dummy variable equal to 1 if there are dividend restrictions.

GUARANTOR : Dummy variable equal to 1 if the borrower has a guarantor.

$L O A N S P R E A D$ : Loan spread over LIBOR at origination.

$L E A D B A N K S$ : Number of lead banks in the syndicate.

$M A T U R I T Y$ : Maturity of the loan in years.

$R E N E W A L$ : Dummy variable equal to 1 if the loan is a renewal.

$S E C U R E D$ : Dummy variable equal to 1 if the loan is secured.

$S E N I O R$ : Dummy variable equal to 1 if the loan is senior.

$T E R M L O A N$ : Dummy variable equal to 1 for term loans.

WORK CAPITAL : Dummy variable equal to 1 if the loan is for working capital.

\section{BANK CONTROLS}

$A A A-B K, \ldots B-B K$ : credit rating of the bank.

ASSETS : Bank assets in 100 million dollars.

$C A P I T A L$ : Equity capital over assets.

$C A P I T A L m k t$ : Market value of equity capital (averaged over the quarter) over total assets.

$C H A R G E O F F S$ : Net charge offs over assets.

LIQUIDITY : Cash plus securities over assets. 
$R O A$ : Net income over assets.

$R O A V O L$ : Standard deviation of the quarterly ROA computed over the last three years. $S U B D E B T$ : Subdebt over assets.

\section{MACROECONOMIC CONTROLS}

$B B B S P D$ : Triple-B minus triple-A yield difference on new industrial rated bonds. $L I B O R$ : 3-month LIBOR at the time of the loan origination. 
Table 1 Sample characterization ${ }^{a}$

\begin{tabular}{|c|c|c|c|c|c|}
\hline \multirow[t]{2}{*}{ Variables } & \multicolumn{3}{|c|}{ Quartiles } & \multirow[t]{2}{*}{ Mean } & \multirow[t]{2}{*}{ Std deviation } \\
\hline & First & Median & Third & & \\
\hline \multicolumn{6}{|c|}{ FIRM CONTROLS } \\
\hline AGE & 7 & 14 & 35 & 21.101 & 16.981 \\
\hline ADVERTISING & 0 & 0 & 0.005 & 0.011 & 0.042 \\
\hline EX RET & -0.574 & 0.369 & 1.404 & 0.449 & 2.430 \\
\hline LEBITDA DEBT & 0.199 & 0.333 & 0.578 & 0.508 & 0.598 \\
\hline LEVERAGE & 0.166 & 0.293 & 0.417 & 0.306 & 0.207 \\
\hline LINTCOV & 1.399 & 1.921 & 2.589 & 2.040 & 1.122 \\
\hline MKTOBOOK & 1.139 & 1.445 & 1.992 & 1.785 & 1.307 \\
\hline NWC & 0.060 & 0.461 & 1.362 & 7.100 & 82.852 \\
\hline PDEFAULT & 0.000 & 0.000 & 0.001 & 0.0468 & 0.1541 \\
\hline PROF MARGIN & 0.006 & 0.037 & 0.071 & 0.003 & 0.233 \\
\hline $\mathrm{R} \& \mathrm{D}$ & 0 & 0 & 0.015 & 0.021 & 0.055 \\
\hline SALES & 2.601 & 7.601 & 27.914 & 37.830 & 112.585 \\
\hline VOL & 18.745 & 26.541 & 38.434 & 31.632 & 20.028 \\
\hline TANGIBLES & 0.455 & 0.703 & 0.970 & 0.719 & 0.358 \\
\hline BETA & 0.390 & 0.645 & 0.952 & 0.694 & 0.443 \\
\hline BETAw & 0.418 & 0.812 & 1.301 & 0.832 & 1.875 \\
\hline BETAm & 0.452 & 0.839 & 1.255 & 0.915 & 0.749 \\
\hline AAA & & & & 0.005 & \\
\hline $\mathrm{AA}$ & & & & 0.020 & \\
\hline A & & & & 0.104 & \\
\hline $\mathrm{BBB}$ & & & & 0.143 & \\
\hline $\mathrm{BB}$ & & & & 0.127 & \\
\hline B & & & & 0.064 & \\
\hline $\mathrm{CCC}$ & & & & 0.003 & \\
\hline $\mathrm{CC}$ & & & & 0.003 & \\
\hline \multicolumn{6}{|c|}{ LOAN CONTROLS } \\
\hline AMOUNT & 0.100 & 0.200 & 0.398 & 0.440 & 1.144 \\
\hline CORPURPOSES & & & & 0.296 & \\
\hline CREDIT LINE & & & & 0.588 & \\
\hline DEBT REPAY & & & & 0.213 & \\
\hline DIVIDEND REST & & & & 0.470 & \\
\hline GUARANTOR & & & & 0.054 & \\
\hline LEAD BANKS & 1 & 1 & 1 & 1.174 & \\
\hline MATURITY & 1.5 & 3.5 & 5 & 3.592 & 2.119 \\
\hline RENEWAL & & & & 0.011 & \\
\hline SECURED & & & & 0.467 & \\
\hline SENIOR & & & & 0.958 & \\
\hline TERM LOAN & & & & 0.222 & \\
\hline WORK CAPITAL & & & & 0.184 & \\
\hline \multicolumn{6}{|c|}{ BANK CONTROLS } \\
\hline ASSETS & 349.814 & 2104.87 & 6141.02 & 3400.46 & 3736.54 \\
\hline CAPITAL & 6.219 & 7.416 & 8.438 & 7.479 & 1.593 \\
\hline CAPITALmkt & 9.540 & 13.362 & 17.697 & 13.876 & 6.414 \\
\hline CHARGE OFFS & 0.357 & 0.741 & 1.266 & 1.235 & 1.975 \\
\hline LIQUIDITY & 0.164 & 0.207 & 0.259 & 0.213 & 0.085 \\
\hline $\mathrm{ROA}$ & 0.877 & 1.412 & 1.798 & 1.307 & 0.858 \\
\hline ROA VOL & 0.584 & 0.932 & 1.267 & 1.227 & 1.356 \\
\hline SUBDEBT & 0.014 & 0.019 & 0.025 & 0.018 & 0.009 \\
\hline AAA-BK & & & & 0.012 & \\
\hline AA-BK & & & & 0.164 & \\
\hline $\mathrm{A}-\mathrm{BK}$ & & & & 0.463 & \\
\hline BBB-BK & & & & 0.023 & \\
\hline BB-BK & & & & 0.001 & \\
\hline \multicolumn{6}{|c|}{ MARKET CONTROLS } \\
\hline BBBSPD & 0.607 & 0.839 & 1.102 & 0.931 & 0.459 \\
\hline LIBOR & 2.794 & 5.130 & 5.700 & 4.472 & 2.009 \\
\hline
\end{tabular}

$a$ Number of observations (loans) in the sample is 15985. See Appendix 1 for the definitions of all variables reported in the table. 
Table 2 Sample characterization: Means for dependent vs non-dependent borrowers ${ }^{a}$

\begin{tabular}{lrrrrrr}
\hline \hline Variables & \multicolumn{2}{c}{1} & \multicolumn{2}{c}{2} & \multicolumn{2}{c}{3} \\
\cline { 2 - 7 } & \multicolumn{1}{c}{ Dep } & Non-dep & Dep & Non-dep & Dep & Non-dep \\
\hline CAPITAL & 7.543 & 7.207 & 7.600 & 7.342 & 7.554 & 7.212 \\
LEBITDA DEBT & 0.511 & 0.496 & 0.603 & 0.400 & 0.543 & 0.384 \\
LINTCOV & 1.989 & 2.260 & 2.158 & 1.906 & 2.066 & 1.948 \\
PDEFAULT & 0.056 & 0.010 & 0.052 & 0.041 & 0.053 & 0.024 \\
VOL & 34.518 & 19.287 & 37.866 & 24.565 & 34.250 & 22.287 \\
BETA & 0.683 & 0.744 & 0.607 & 0.793 & 0.669 & 0.787 \\
BETAw & 0.845 & 0.777 & 0.766 & 0.907 & 0.817 & 0.888 \\
BETAm & 0.956 & 0.742 & 0.940 & 0.887 & 0.930 & 0.861 \\
Observations & 12956 & 3029 & 8493 & 7492 & 12487 & 3498 \\
\hline Variables & & 4 & & 5 & & 6 \\
& Dep & Non-dep & Dep & Non-dep & Dep & Non-dep \\
\hline CAPITAL & 7.616 & 7.435 & 7.450 & 7.643 & 7.412 & 7.633 \\
LEBITDA DEBT & 0.541 & 0.497 & 0.516 & 0.502 & 0.529 & 0.527 \\
LINTCOV & 1.897 & 2.087 & 2.065 & 2.040 & 2.086 & 2.058 \\
PDEFAULT & 0.071 & 0.039 & 0.054 & 0.041 & 0.053 & 0.040 \\
VOL & 44.205 & 27.504 & 33.110 & 30.438 & 33.707 & 31.911 \\
BETA & 0.572 & 0.735 & 0.726 & 0.664 & 0.653 & 0.704 \\
BETAw & 0.746 & 0.860 & 0.874 & 0.782 & 0.754 & 0.854 \\
BETAm & 0.960 & 0.900 & 0.909 & 0.907 & 0.910 & 0.926 \\
Observations & 3951 & 12034 & 6793 & 8618 & 5532 & 5874 \\
\hline \hline Column & & & & & \\
\hline
\end{tabular}

${ }_{a} \overline{\overline{\text { Column } 1 \text { reports the results for borrowers without and those with a commercial paper rating, respectively; }}}$ Column 2 reports the results for borrowers without and those with a credit rating, respectively; Column 3 reports the results for borrowers that did not issue and those that issued a public bond in the last three years, respectively; Column 4 reports the results for borrowers that take out loans from a single bank and those that take out loans from multiple banks, respectively; Column 5 reports the results for borrowers that take out loans from a bank that extended more than 50 percent of the loans the borrower took out over the last three years and those that take out loans from a bank that extended less or equal than 50 percent of the loans the borrower took out over the last three years, respectively; Column 6 reports the results for borrowers that take out loans from a bank that extended more or equal to 75 percent of the loans the borrower took out over the last three years and those that take out loans from a bank that extended less or equal than 25 percent of the loans the borrower took out over the last three years, respectively; The unit of observation in this table is a loan. See table 1 for the definition of the variables in the table. 
Table 3 Loan spread and bank capital ${ }^{a}$

\begin{tabular}{|c|c|c|c|}
\hline Variables & 1 & 2 & 3 \\
\hline \multicolumn{4}{|l|}{ BANK CONTROLS } \\
\hline \multirow[t]{2}{*}{ CAPITAL } & $-2.882^{* * *}$ & $-2.724^{* * *}$ & $-2.874^{* * *}$ \\
\hline & $(-3.29)$ & $(-3.54)$ & $(-3.00)$ \\
\hline \multirow[t]{2}{*}{ CHARGE OFFS } & -0.387 & -0.173 & 0.105 \\
\hline & $(-0.67)$ & $(-0.34)$ & $(0.13)$ \\
\hline \multirow[t]{2}{*}{ LASSETS } & $-3.694^{* * *}$ & $-2.210^{* *}$ & -2.215 \\
\hline & $(-3.64)$ & $(-2.53)$ & $(-0.68)$ \\
\hline \multirow[t]{2}{*}{ LIQUIDITY } & 17.122 & 10.224 & -24.613 \\
\hline & $(1.11)$ & $(0.75)$ & $(-1.26)$ \\
\hline \multirow[t]{2}{*}{ ROA } & $-3.723^{* * *}$ & $-3.593^{* * *}$ & $-2.295^{*}$ \\
\hline & $(-2.97)$ & $(-3.08)$ & $(-1.95)$ \\
\hline \multirow[t]{2}{*}{ ROA VOL } & 0.319 & -0.006 & -1.027 \\
\hline & $(0.34)$ & $(-0.01)$ & $(-1.25)$ \\
\hline \multirow[t]{2}{*}{ SUBDEBT } & $-375.418^{* *}$ & -149.318 & 196.829 \\
\hline & $(-2.45)$ & $(-1.07)$ & (1.11) \\
\hline \multirow[t]{2}{*}{ AAA-BK } & $-16.419^{* *}$ & -6.899 & -7.512 \\
\hline & $(-2.23)$ & $(-1.04)$ & $(-0.73)$ \\
\hline \multirow[t]{2}{*}{ AA-BK } & $-7.027^{*}$ & -3.202 & -1.854 \\
\hline & $(-1.88)$ & $(-1.02)$ & $(-0.41)$ \\
\hline \multirow[t]{2}{*}{$\mathrm{A}-\mathrm{BK}$} & $-9.575 * * *$ & $-5.645^{* *}$ & 1.360 \\
\hline & $(-2.99)$ & $(-2.10)$ & $(0.35)$ \\
\hline \multirow[t]{2}{*}{ BBB-BK } & -6.220 & -6.187 & 0.038 \\
\hline & $(-0.64)$ & $(-0.81)$ & $(0.00)$ \\
\hline \multirow[t]{2}{*}{ BB-BK } & 22.696 & 21.981 & 25.866 \\
\hline & $(1.18)$ & $(1.08)$ & (1.19) \\
\hline \multirow[t]{2}{*}{ B-BK } & $108.736^{* * *}$ & $101.047^{* * *}$ & $73.083^{* * *}$ \\
\hline & $(10.70)$ & $(10.73)$ & $(4.74)$ \\
\hline \multicolumn{4}{|l|}{ FIRM CONTROLS } \\
\hline \multirow[t]{2}{*}{ ADVERTISING } & $-33.858^{*}$ & -16.015 & -19.701 \\
\hline & $(-1.70)$ & $(-0.73)$ & $(-0.86)$ \\
\hline \multirow[t]{2}{*}{ EXRET } & $-1.749^{* *}$ & $-1.613^{* * *}$ & $-1.500 * * *$ \\
\hline & $(-2.55)$ & $(-2.84)$ & $(-2.66)$ \\
\hline \multirow[t]{2}{*}{ LAGE } & $-4.891^{* * *}$ & $-4.143^{* * *}$ & $-3.879 * * *$ \\
\hline & $(-3.44)$ & $(-3.19)$ & $(-2.95)$ \\
\hline \multirow[t]{2}{*}{ LEVERAGE } & $21.716^{* * *}$ & $20.290 * * *$ & $21.122^{* * *}$ \\
\hline & $(3.05)$ & $(3.07)$ & $(3.22)$ \\
\hline LINTCOV & $-16.896^{* * *}$ & $-13.470^{* * *}$ & $-13.007^{* * *}$ \\
\hline & $(-13.73)$ & $(-11.87)$ & $(-11.44)$ \\
\hline LSALES & $-19.643^{* * *}$ & $-5.788 * * *$ & $-6.223^{* * *}$ \\
\hline & $(-10.94)$ & $(-3.79)$ & $(-3.97)$ \\
\hline MKTOBOOK & $-5.854^{* * *}$ & $-4.183^{* * *}$ & $-4.578 * * *$ \\
\hline & $(-7.08)$ & $(-5.89)$ & $(-6.37)$ \\
\hline NWC & $-0.017^{* *}$ & $-0.011^{* *}$ & $-0.009^{*}$ \\
\hline & $(-2.42)$ & $(-2.02)$ & $(-1.71)$ \\
\hline PDEFAULT & $83.248^{* * *}$ & $86.292^{* * *}$ & $91.390 * * *$ \\
\hline & $(6.39)$ & $(7.14)$ & $(7.44)$ \\
\hline PROFMARGIN & -7.179 & -8.920 & -8.160 \\
\hline & $(-1.21)$ & $(-1.60)$ & $(-1.45)$ \\
\hline $\mathrm{RD}$ & -16.129 & -24.670 & $-72.003^{* * *}$ \\
\hline & $(-0.69)$ & $(-1.11)$ & $(-3.09)$ \\
\hline TANGIBLES & $-6.446^{*}$ & -2.189 & -1.769 \\
\hline & $(-1.86)$ & $(-0.67)$ & $(-0.53)$ \\
\hline VOL & $1.506^{* * *}$ & $1.041^{* * *}$ & $0.965^{* * *}$ \\
\hline & $(12.38)$ & $(9.86)$ & (8.92) \\
\hline AAA & $-18.272^{*}$ & $-19.710^{* *}$ & $-19.072^{* *}$ \\
\hline & $(-1.81)$ & $(-2.32)$ & $(-2.26)$ \\
\hline
\end{tabular}


Table 3 Continued $^{a}$

\begin{tabular}{|c|c|c|c|}
\hline Variables & 1 & 2 & 3 \\
\hline \multirow[t]{2}{*}{$\overline{\mathrm{AA}}$} & $-51.249^{* * *}$ & $-40.638^{* * *}$ & $-42.589^{* * *}$ \\
\hline & $(-7.83)$ & $(-7.76)$ & $(-8.04)$ \\
\hline \multirow[t]{2}{*}{ A } & $-64.161^{* * *}$ & $-47.383^{* * *}$ & $-49.992^{* * *}$ \\
\hline & $(-12.50)$ & $(-11.34)$ & $(-11.88)$ \\
\hline \multirow[t]{2}{*}{$\mathrm{BBB}$} & $-42.664^{* * *}$ & $-24.917^{* * *}$ & $-27.131^{* * *}$ \\
\hline & $(-9.96)$ & $(-7.04)$ & $(-7.61)$ \\
\hline \multirow[t]{2}{*}{ BB } & $13.624^{* * *}$ & $10.826^{* * *}$ & $8.940^{* * *}$ \\
\hline & $(3.67)$ & $(3.11)$ & $(2.59)$ \\
\hline \multirow[t]{2}{*}{ B } & $40.207^{* * *}$ & $35.102^{* * *}$ & $34.891^{* * *}$ \\
\hline & $(7.01)$ & $(6.41)$ & $(6.22)$ \\
\hline \multirow[t]{2}{*}{$\mathrm{CCC}$} & $44.824^{* *}$ & $38.113^{*}$ & $34.418^{*}$ \\
\hline & $(2.16)$ & $(1.93)$ & $(1.73)$ \\
\hline \multirow[t]{2}{*}{$\mathrm{CC}$} & $-91.622 * * *$ & $-88.150 * * *$ & $-91.382 * * *$ \\
\hline & $(-3.87)$ & $(-4.21)$ & $(-4.36)$ \\
\hline \multicolumn{4}{|l|}{ LOAN CONTROLS } \\
\hline \multirow{2}{*}{ COR PURPOSES } & & $-11.358^{* * *}$ & $-11.519^{* * *}$ \\
\hline & & $(-3.79)$ & $(-3.89)$ \\
\hline \multirow[t]{2}{*}{ DEBT REPAY } & & $-17.521^{* * *}$ & $-17.800^{* * *}$ \\
\hline & & $(-6.62)$ & $(-6.80)$ \\
\hline \multirow[t]{2}{*}{ DIV RESTRICT } & & 0.251 & 1.822 \\
\hline & & $(0.11)$ & $(0.78)$ \\
\hline \multirow[t]{2}{*}{ CREDIT LINE } & & $12.052^{* * *}$ & $12.912^{* * *}$ \\
\hline & & $(4.48)$ & $(4.86)$ \\
\hline \multirow[t]{2}{*}{ GUARANTOR } & & 6.544 & 6.663 \\
\hline & & $(1.41)$ & $(1.44)$ \\
\hline \multirow[t]{2}{*}{ LAMOUNT } & & $-13.909 * * *$ & $-12.312^{* * *}$ \\
\hline & & $(-13.15)$ & $(-11.54)$ \\
\hline \multirow[t]{2}{*}{ LEAD BANKS } & & 1.401 & 2.689 \\
\hline & & $(0.51)$ & $(1.02)$ \\
\hline \multirow[t]{2}{*}{ LMATURITY } & & $-10.715^{* * *}$ & $-9.569 * * *$ \\
\hline & & $(-6.65)$ & $(-5.91)$ \\
\hline \multirow[t]{2}{*}{ RENEWAL } & & -4.341 & -3.120 \\
\hline & & $(-0.62)$ & $(-0.43)$ \\
\hline \multirow[t]{2}{*}{ SECURED } & & $49.921 * * *$ & $47.846^{* * *}$ \\
\hline & & $(19.56)$ & (18.67) \\
\hline \multirow[t]{2}{*}{ SENIOR } & & $-20.068^{* * *}$ & $-20.540 * * *$ \\
\hline & & $(-3.61)$ & $(-3.67)$ \\
\hline \multirow[t]{2}{*}{ TERM LOAN } & & $53.244^{* * *}$ & $54.446^{* * *}$ \\
\hline & & $(15.05)$ & $(15.58)$ \\
\hline \multirow[t]{2}{*}{ WORK CAPITAL } & & $-23.154^{* * *}$ & $-22.738^{* * *}$ \\
\hline & & $(-6.96)$ & $(-6.88)$ \\
\hline BUSINESS CONTI & & & \\
\hline BBBSPD & 4.000 & 4.361 & 7.696 \\
\hline & $(0.38)$ & $(0.47)$ & $(0.84)$ \\
\hline LIBOR & -4.265 & -3.300 & -4.838 \\
\hline & $(-0.69)$ & $(-0.61)$ & $(-0.93)$ \\
\hline Bank fixed effects & No & No & Yes \\
\hline Constant & $358.505^{* * *}$ & $320.108^{* * *}$ & $316.904^{* * *}$ \\
\hline & $(8.67)$ & $(8.98)$ & $(7.15)$ \\
\hline Observations & 15985 & 15985 & 15985 \\
\hline R-squared & 0.524 & 0.599 & 0.623 \\
\hline
\end{tabular}

${ }^{a}$ The dependent variable is LOAN SPREAD: Loan spread over LIBOR at the time of the loan origination. Included in the regressions are year-quarter dummy variables and dummy variables for the issuer's sector of activity as defined by SIC one-digit code. Models estimated with robust standard errors, clustered by firm and by bank. We report t statistics in parentheses. *** denotes $1 \%$ significant level, ${ }^{* *}$ denotes $5 \%$ significant level, and $*$ denotes $10 \%$ significant level. 
Table 4 Loan spread, bank capital, and borrowers' cash flow ${ }^{a}$

\begin{tabular}{|c|c|c|c|c|}
\hline Variables & 1 & 2 & 3 & 4 \\
\hline CAPITAL & $\begin{array}{r}-6.16^{* * *} \\
(-4.24)\end{array}$ & $\begin{array}{r}-6.73^{* * *} \\
(-4.13)\end{array}$ & & \\
\hline LINTCOV & $\begin{array}{r}-20.89 * * * \\
(-4.31)\end{array}$ & $\begin{array}{r}-22.51^{* * *} \\
(-4.31)\end{array}$ & $\begin{array}{r}-22.18^{* * *} \\
(-3.74)\end{array}$ & $\begin{array}{r}-20.86 * * * \\
(-2.87)\end{array}$ \\
\hline$C A P I T A L \times L I N T C O V$ & $\begin{array}{r}1.67 * * * \\
(2.94)\end{array}$ & $\begin{array}{r}1.96 * * * \\
(3.26)\end{array}$ & $\begin{array}{r}1.98^{* * *} \\
(2.65)\end{array}$ & $\begin{array}{r}1.69^{* *} \\
(1.97)\end{array}$ \\
\hline VOL & $\begin{array}{r}1.04^{* * *} \\
(9.74)\end{array}$ & $\begin{array}{r}0.96^{* * *} \\
(8.80)\end{array}$ & $\begin{array}{r}1.05^{* * *} \\
(7.41)\end{array}$ & \\
\hline PDEFAULT & $\begin{array}{r}82.54^{* * *} \\
(6.89)\end{array}$ & $\begin{array}{r}87.32^{* * *} \\
(7.17)\end{array}$ & $\begin{array}{r}85.06^{* * *} \\
(5.35)\end{array}$ & \\
\hline$B B B S P D$ & $\begin{array}{r}16.81 \\
(1.62)\end{array}$ & $\begin{array}{r}20.67^{* *} \\
(2.00)\end{array}$ & $\begin{array}{r}27.00 * * * \\
(2.72)\end{array}$ & $\begin{array}{r}67.31^{* * *} \\
(6.10)\end{array}$ \\
\hline$B B B S P D \times L I N T C O V$ & $\begin{array}{r}-6.07 * * * \\
(-3.05) \\
\end{array}$ & $\begin{array}{r}-6.21^{* * *} \\
(-2.88) \\
\end{array}$ & $\begin{array}{r}-7.55 * * * \\
(-3.64)\end{array}$ & $\begin{array}{r}-17.55^{* * *} \\
(-7.01) \\
\end{array}$ \\
\hline constant & $\begin{array}{r}336.40^{* * *} \\
(8.79)\end{array}$ & $\begin{array}{r}341.76^{* * *} \\
(7.32)\end{array}$ & & \\
\hline Observations & 15985 & 15985 & 15008 & 13852 \\
\hline R-squared & 0.601 & 0.624 & 0.685 & 0.816 \\
\hline BANK CONTROLS & YES & YES & $\mathrm{NO}$ & $\mathrm{NO}$ \\
\hline FIRM CONTROLS & YES & YES & YES & $\mathrm{NO}$ \\
\hline LOAN CONTROLS & YES & YES & YES & $\mathrm{NO}$ \\
\hline BANK FIXED EFFECTS & $\mathrm{NO}$ & YES & $\mathrm{NO}$ & $\mathrm{NO}$ \\
\hline BANK-TIME FIXED EFFECTS & $\mathrm{NO}$ & $\mathrm{NO}$ & YES & YES \\
\hline BORROWER FIXED EFFECTS & NO & NO & $\mathrm{NO}$ & YES \\
\hline
\end{tabular}

$a$ The dependent variable is LOAN SPREAD: Loan spread over LIBOR at the time of the loan origination. BANK, FIRM and LOAN controls are the set of controls reported in model 3 of Table 3 . Included in the regressions are also time (year-quarter) fixed effects and dummy variables for the issuer's sector of activity as defined by SIC one-digit code. See Appendix 1 for the definitions of all controls included in the models. Models estimated with robust standard errors, clustered by firm and by bank. We report t statistics in parentheses. *** denotes $1 \%$ significant level, ** denotes $5 \%$ significant level, and * denotes $10 \%$ significant level. 
Table 5 Loan spread, bank capital, and borrowers' cash flow: Dep vs. nondep borrowers ${ }^{a}$

\begin{tabular}{|c|c|c|c|c|c|c|}
\hline \multicolumn{7}{|c|}{ Panel A: Bank-dependent borrowers } \\
\hline Variables & 1 & 2 & 3 & 4 & 5 & 6 \\
\hline CAPITAL & $\begin{array}{r}-7.88^{* * *} \\
(-4.74)\end{array}$ & $\begin{array}{r}-7.54^{* * *} \\
(-4.12)\end{array}$ & $\begin{array}{r}-7.31^{* * *} \\
(-4.27)\end{array}$ & $\begin{array}{r}-7.66^{* * *} \\
(-3.95)\end{array}$ & $\begin{array}{r}-8.81^{* * *} \\
(-3.75)\end{array}$ & $\begin{array}{r}-9.06^{* * *} \\
(-3.78)\end{array}$ \\
\hline LINTCOV & $\begin{array}{r}-25.17^{* * *} \\
(-4.82)\end{array}$ & $\begin{array}{r}-22.88^{* * *} \\
(-4.45)\end{array}$ & $\begin{array}{r}-22.08^{* * *} \\
(-4.35)\end{array}$ & $\begin{array}{r}-21.79 * * * \\
(-4.64)\end{array}$ & $\begin{array}{r}-31.79 * * * \\
(-3.79)\end{array}$ & $\begin{array}{r}-26.93^{* * *} \\
(-3.53)\end{array}$ \\
\hline$C A P I T A L \times L I N T C O V$ & $\begin{array}{r}2.30^{* * *} \\
(3.76)\end{array}$ & $\begin{array}{r}2.08^{* * *} \\
(3.28)\end{array}$ & $\begin{array}{r}2.03^{* * *} \\
(3.44)\end{array}$ & $\begin{array}{r}1.78^{* * *} \\
(2.81)\end{array}$ & $\begin{array}{r}2.95^{* * *} \\
(2.88)\end{array}$ & $\begin{array}{r}2.40^{* * *} \\
(2.69)\end{array}$ \\
\hline VOL & $\begin{array}{r}0.89^{* * *} \\
(8.16)\end{array}$ & $\begin{array}{r}0.71^{* * *} \\
(6.33)\end{array}$ & $\begin{array}{r}0.98^{* * *} \\
(8.85)\end{array}$ & $\begin{array}{r}0.77^{* * *} \\
(5.66)\end{array}$ & $\begin{array}{r}1.00^{* * *} \\
(5.25)\end{array}$ & $\begin{array}{r}0.94^{* * *} \\
(5.18)\end{array}$ \\
\hline PDEFAULT & $\begin{array}{r}80.50^{* * *} \\
(6.73)\end{array}$ & $\begin{array}{r}78.09^{* * *} \\
(4.99)\end{array}$ & $\begin{array}{r}73.58^{* * *} \\
(6.76)\end{array}$ & $\begin{array}{r}48.06^{* * *} \\
(2.70)\end{array}$ & $\begin{array}{r}77.55^{* * *} \\
(4.88)\end{array}$ & $\begin{array}{r}75.25^{* * *} \\
(4.52)\end{array}$ \\
\hline$B B B S P D$ & $\begin{array}{r}18.28 \\
(1.55)\end{array}$ & $\begin{array}{l}14.14 \\
(0.91)\end{array}$ & $\begin{array}{r}19.91 \\
(1.56)\end{array}$ & $\begin{array}{r}-3.65 \\
(-0.15)\end{array}$ & $\begin{array}{r}25.62^{*} \\
(1.82)\end{array}$ & $\begin{array}{r}24.19 \\
(1.42)\end{array}$ \\
\hline$B B B S P D \times L I N T C O V$ & $\begin{array}{r}-6.48^{* * *} \\
(-2.90)\end{array}$ & $\begin{array}{l}-4.48^{*} \\
(-1.94)\end{array}$ & $\begin{array}{r}-6.56^{* * *} \\
(-3.01)\end{array}$ & $\begin{array}{r}-1.94 \\
(-0.80)\end{array}$ & $\begin{array}{l}-5.97^{*} \\
(-1.83)\end{array}$ & $\begin{array}{l}-6.32^{*} \\
(-1.84)\end{array}$ \\
\hline Constant & $\begin{array}{r}388.24^{* * *} \\
(7.53)\end{array}$ & $\begin{array}{r}427.99^{* * *} \\
(6.57)\end{array}$ & $\begin{array}{r}290.13^{* * *} \\
(3.68)\end{array}$ & $\begin{array}{r}317.29^{* * *} \\
(3.56)\end{array}$ & $\begin{array}{r}368.79^{* * *} \\
(4.09)\end{array}$ & $\begin{array}{r}364.98^{* * * *} \\
(3.56)\end{array}$ \\
\hline $\begin{array}{l}\text { Observations } \\
\text { R-squared }\end{array}$ & $\begin{array}{r}12956 \\
0.549\end{array}$ & $\begin{array}{r}8493 \\
0.558\end{array}$ & $\begin{array}{r}12487 \\
0.591\end{array}$ & $\begin{array}{r}3951 \\
0.570\end{array}$ & $\begin{array}{r}6793 \\
0.640\end{array}$ & $\begin{array}{r}5532 \\
0.651\end{array}$ \\
\hline $\begin{array}{l}\mathrm{p} \text { value for } H_{0}: \\
\delta_{1}+\delta_{2} \times L I N \bar{T} C O V=0 \\
\delta_{1}+\delta_{2} \times(L I N \bar{T} C O V-\sigma)=0 \\
\delta_{1}+\delta_{2} \times(L I N \bar{T} C O V+\sigma)=0\end{array}$ & $\begin{array}{l}0.0013 \\
0.0000 \\
0.6272\end{array}$ & $\begin{array}{l}0.0113 \\
0.0001 \\
0.8487\end{array}$ & $\begin{array}{l}0.0035 \\
0.0000 \\
0.5799\end{array}$ & $\begin{array}{l}0.0052 \\
0.0001 \\
0.3177\end{array}$ & $\begin{array}{l}0.0533 \\
0.0003 \\
0.7546\end{array}$ & $\begin{array}{l}0.0060 \\
0.0002 \\
0.4817\end{array}$ \\
\hline Panel B: Non-dependent borrow & vers & & & & & \\
\hline Variables & 1 & 2 & 3 & 4 & 5 & 6 \\
\hline CAPITAL & $\begin{array}{r}3.50 \\
(1.03)\end{array}$ & $\begin{array}{r}-1.24 \\
(-0.45)\end{array}$ & $\begin{array}{r}-4.51 \\
(-1.46)\end{array}$ & $\begin{array}{r}-1.96 \\
(-0.88)\end{array}$ & $\begin{array}{r}-5.34^{* * *} \\
(-2.62)\end{array}$ & $\begin{array}{r}-5.96^{* *} \\
(-2.56)\end{array}$ \\
\hline LINTCOV & $\begin{array}{r}9.67 \\
(0.87)\end{array}$ & $\begin{array}{r}-6.87 \\
(-0.68)\end{array}$ & $\begin{array}{r}-23.78^{*} \\
(-1.78)\end{array}$ & $\begin{array}{l}-10.50 \\
(-1.32)\end{array}$ & $\begin{array}{r}-15.01^{* *} \\
(-2.44)\end{array}$ & $\begin{array}{r}-17.87^{* * *} \\
(-2.68)\end{array}$ \\
\hline$C A P I T A L \times L I N T C O V$ & $\begin{array}{r}-1.34 \\
(-1.12)\end{array}$ & $\begin{array}{r}-0.02 \\
(-0.01)\end{array}$ & $\begin{array}{r}1.59 \\
(1.09)\end{array}$ & $\begin{array}{r}0.58 \\
(0.61)\end{array}$ & $\begin{array}{c}1.20^{*} \\
(1.65)\end{array}$ & $\begin{array}{r}1.53^{*} \\
(1.91)\end{array}$ \\
\hline VOL & $\begin{array}{r}1.39^{* * *} \\
(5.93)\end{array}$ & $\begin{array}{r}1.43^{* * *} \\
(5.94)\end{array}$ & $\begin{array}{r}0.79^{* *} \\
(2.16)\end{array}$ & $\begin{array}{r}1.16^{* * * *} \\
(7.38)\end{array}$ & $\begin{array}{r}0.90^{* * * *} \\
(6.87)\end{array}$ & $\begin{array}{r}1.01^{* * *} \\
(8.16)\end{array}$ \\
\hline PDEFAULT & $\begin{array}{r}172.49^{* * *} \\
(3.00)\end{array}$ & $\begin{array}{r}91.55^{* * *} \\
(4.64)\end{array}$ & $\begin{array}{r}170.54^{* * *} \\
(4.86)\end{array}$ & $\begin{array}{r}104.11^{* * * *} \\
(6.94)\end{array}$ & $\begin{array}{r}100.47^{* * *} \\
(5.63)\end{array}$ & $\begin{array}{r}63.88^{* * *} \\
(3.96)\end{array}$ \\
\hline$B B B S P D$ & $\begin{array}{r}27.25 \\
(1.35)\end{array}$ & $\begin{array}{r}30.15^{*} \\
(1.81)\end{array}$ & $\begin{array}{r}19.80 \\
(1.05)\end{array}$ & $\begin{array}{r}33.84^{* * * *} \\
(2.73)\end{array}$ & $\begin{array}{r}25.94^{*} \\
(1.80)\end{array}$ & $\begin{array}{r}1.34 \\
(0.08)\end{array}$ \\
\hline$B B B S P D \times L I N T C O V$ & $\begin{array}{r}-11.50^{* *} \\
(-2.43) \\
\end{array}$ & $\begin{array}{r}-10.91^{* * *} \\
(-2.64) \\
\end{array}$ & $\begin{array}{r}-7.73 \\
(-1.40) \\
\end{array}$ & $\begin{array}{r}-9.98 * * * \\
(-3.48) \\
\end{array}$ & $\begin{array}{r}-6.90^{* * *} \\
(-2.94) \\
\end{array}$ & $\begin{array}{r}-5.29 * * \\
(-2.10) \\
\end{array}$ \\
\hline Constant & $\begin{array}{r}92.32 \\
(1.47)\end{array}$ & $\begin{array}{r}109.60 \\
(1.09)\end{array}$ & $\begin{array}{r}367.64^{* * *} \\
(3.28)\end{array}$ & $\begin{array}{r}303.73^{* * *} \\
(5.33)\end{array}$ & $\begin{array}{r}226.42^{* * *} \\
(3.98)\end{array}$ & $\begin{array}{r}360.32^{* * *} \\
(5.00)\end{array}$ \\
\hline Observations & 3029 & 7492 & 3498 & 12034 & 8618 & 5874 \\
\hline R-squared & 0.630 & 0.667 & 0.690 & 0.626 & 0.640 & 0.637 \\
\hline $\begin{array}{l}\mathrm{p} \text { value for } H_{0}: \\
\delta_{1}+\delta_{2} \times L I N \bar{T} C O V=0 \\
\delta_{1}+\delta_{2} \times(L I N \bar{T} C O V-\sigma)=0 \\
\delta_{1}+\delta_{2} \times(L I N \bar{T} C O V+\sigma)=0\end{array}$ & $\begin{array}{l}0.7208 \\
0.4258 \\
0.7207 \\
\end{array}$ & $\begin{array}{l}0.3282 \\
0.4666 \\
0.3853 \\
\end{array}$ & $\begin{array}{l}0.3579 \\
0.1484 \\
0.9014 \\
\end{array}$ & $\begin{array}{l}0.4795 \\
0.3489 \\
0.9149 \\
\end{array}$ & $\begin{array}{l}0.0136 \\
0.0058 \\
0.2359 \\
\end{array}$ & $\begin{array}{l}0.0357 \\
0.0101 \\
0.4928 \\
\end{array}$ \\
\hline
\end{tabular}

${ }^{a}$ The dependent variable is LOAN SPREAD: Loan spread over LIBOR at the time of the loan origination. Models 1 and 7 in the top (bottom) panel reports the results for loans of borrowers without (with) a commercial paper rating; Models 2 and 8 in the top (bottom) pane; reports the results for loans of borrowers without (with) a credit rating; Models 3 and 9 in the top (bottom) panel reports the results for loans of borrowers that did not issue (issued) a public bond in the last three years; Models 4 and 10 in the top (bottom) panel reports the results for loans taken out from a single (multiple) bank(s); Models 5 and 11 in the top (bottom) reports the results for loans taken out from a bank that extended more than (less or equal) 50 percent of the loans the borrower took out over the last three years; Models 6 and 12 in the top (bottom) reports the results for loans taken out from a bank that extended 75 (25) percent or more (less) of the loans the borrower took out over the last three years. Included in the regressions are all of the firm, loan and bank controls used in model 3 of Table 
3 , as well as time (year-quarter) fixed effects and dummy variables for the issuer's sector of activity as defined by SIC one-digit code. See Appendix 1 for the definitions of all controls included in the models. Models estimated with bank fixed effects, and robust standard errors, clustered by firm and by bank. We report $\mathrm{t}$ statistics in parentheses. ${ }^{* * *}$ denotes $1 \%$ significant level, ${ }^{* *}$ denotes $5 \%$ significant level, and ${ }^{*}$ denotes $10 \%$ significant level. 
Table 6 Spread effect for different levels of bank capital and borrower cash flow computed off Table $5^{a}$

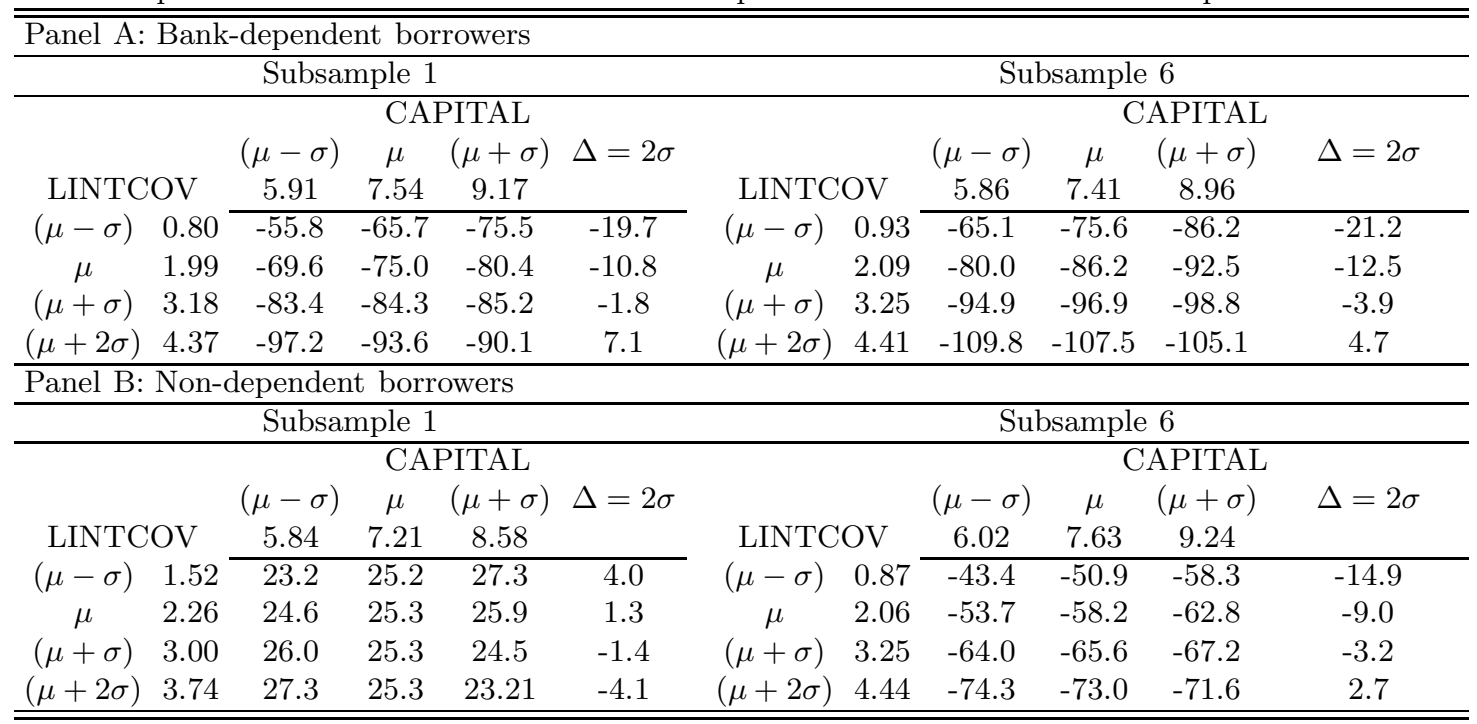

a This table reports the total spread effects of different combinations of bank capital and borrower cash flow levels for bank-dependent borrowers (top panel) and non-dependent borrowers (bottom panel) computed off the estimates reported in Table 5 for subsamples (1) and (6). Subsample 1 identifies borrowers as bank dependent (non-dependent) if they do not have (have) a commercial paper rating. Subsample 6 identifies borrowers as bank dependent (non-dependent) if they take out the loan from a bank that extended 75 (25) percent or more (less) of the loans the borrower took out over the last three years. 
Table 7 Loan spread, bank capital, borrowers' cash flow and risk (VOL): Dep vs. nondep borrowers ${ }^{a}$ Panel A: Bank-dependent borrowers

\begin{tabular}{|c|c|c|c|c|c|c|}
\hline Variables & 1 & 2 & 3 & 4 & 5 & 6 \\
\hline \multirow[t]{2}{*}{ CAPITAL } & $-5.35^{* *}$ & $-4.92^{*}$ & -3.58 & -3.45 & $-8.15^{* *}$ & $-10.27 * * *$ \\
\hline & $(-2.19)$ & $(-1.76)$ & $(-1.46)$ & $(-1.01)$ & $(-2.18)$ & $(-2.83)$ \\
\hline \multirow[t]{2}{*}{ LINTCOV } & $-18.91^{* * *}$ & $-17.15^{* * *}$ & $-15.29^{* * *}$ & $-16.40 * * *$ & $-27.39 * * *$ & $-24.06^{* * *}$ \\
\hline & $(-3.80)$ & $(-3.27)$ & $(-3.18)$ & $(-3.07)$ & $(-3.33)$ & $(-3.42)$ \\
\hline \multirow[t]{2}{*}{$C A P I T A L \times L I N T C O V$} & $1.91^{* * *}$ & $1.74^{* * *}$ & $1.51^{* *}$ & $1.36^{*}$ & $2.70^{* * *}$ & $2.34^{* * *}$ \\
\hline & $(3.10)$ & $(2.64)$ & $(2.52)$ & $(1.93)$ & $(2.59)$ & $(2.74)$ \\
\hline \multirow[t]{2}{*}{ VOL } & $1.85^{* * *}$ & $1.59 * * *$ & $1.99^{* * *}$ & $1.64^{* * *}$ & $1.51^{* *}$ & $1.19^{*}$ \\
\hline & $(4.63)$ & $(3.88)$ & $(4.97)$ & $(4.23)$ & $(2.22)$ & $(1.76)$ \\
\hline \multirow[t]{2}{*}{$C A P I T A L \times V O L$} & -0.03 & -0.04 & -0.06 & -0.06 & 0.00 & 0.04 \\
\hline & $(-0.75)$ & $(-0.78)$ & $(-1.32)$ & $(-1.35)$ & $(0.05)$ & $(0.60)$ \\
\hline \multirow[t]{2}{*}{ PDEFAULT } & $82.99 * * *$ & $78.67^{* * *}$ & $75.79 * * *$ & $47.77^{* * *}$ & $79.46^{* * *}$ & $77.32^{* * *}$ \\
\hline & $(6.96)$ & $(5.05)$ & $(6.84)$ & $(2.73)$ & $(5.05)$ & $(4.61)$ \\
\hline \multirow[t]{2}{*}{$B B B S P D$} & $49.96^{* * *}$ & $45.30^{* * *}$ & $45.81^{* * *}$ & 19.61 & $47.12^{* * *}$ & $45.61^{* *}$ \\
\hline & $(3.95)$ & $(2.76)$ & $(3.30)$ & $(0.88)$ & $(2.97)$ & $(2.48)$ \\
\hline \multirow[t]{2}{*}{$B B B S P D \times L I N T C O V$} & $-10.10 * * *$ & $-7.98 * * *$ & $-9.61^{* * *}$ & -4.27 & $-8.64^{* * *}$ & $-8.92 * *$ \\
\hline & $(-4.50)$ & $(-3.34)$ & $(-4.34)$ & $(-1.62)$ & $(-2.63)$ & $(-2.54)$ \\
\hline \multirow[t]{2}{*}{$B B B S P D \times V O L$} & $-0.65^{* * *}$ & $-0.53^{* * *}$ & $-0.50^{* * *}$ & $-0.34^{* *}$ & $-0.49^{* *}$ & $-0.51^{* *}$ \\
\hline & $(-4.83)$ & $(-3.86)$ & $(-3.60)$ & $(-2.27)$ & $(-2.28)$ & $(-2.31)$ \\
\hline \multirow[t]{2}{*}{ Constant } & $330.12^{* * *}$ & $371.46^{* * *}$ & $234.86^{* * *}$ & $261.62^{* * *}$ & $339.12^{* * *}$ & $349.71^{* * *}$ \\
\hline & $(6.16)$ & $(5.47)$ & $(2.92)$ & $(2.95)$ & $(3.73)$ & $(3.42)$ \\
\hline Observations & 12956 & 8493 & 12487 & 3951 & 6793 & 5532 \\
\hline R-squared & 0.552 & 0.560 & 0.593 & 0.572 & 0.641 & 0.652 \\
\hline \multicolumn{7}{|l|}{$\mathrm{p}$ value for $H_{0}$ : } \\
\hline$\delta_{1}+\delta_{2} \times L I N \bar{T} C O V+\delta_{3} \times V \bar{O} L=0$ & 0.0046 & 0.0303 & 0.0101 & 0.0157 & 0.0757 & 0.0071 \\
\hline$\delta_{1}+\delta_{2} \times(L I N \bar{T} C O V-\sigma)+\delta_{3} \times V \bar{O} L=0$ & 0.0000 & 0.0007 & 0.0004 & 0.0027 & 0.0010 & 0.0002 \\
\hline$\delta_{1}+\delta_{2} \times(L I N \bar{T} C O V+\sigma)+\delta_{3} \times V \bar{O} L=0$ & 0.7189 & 0.8939 & 0.5636 & 0.3190 & 0.7665 & 0.4786 \\
\hline \multicolumn{7}{|l|}{ Panel B: Non-dependent borrowers } \\
\hline Variables & 1 & 2 & 3 & 4 & 5 & 6 \\
\hline \multirow[t]{2}{*}{ CAPITAL } & 0.34 & $-6.36^{*}$ & -2.35 & $-6.95^{* *}$ & -0.73 & -2.38 \\
\hline & $(0.09)$ & $(-1.84)$ & $(-0.64)$ & $(-2.37)$ & $(-0.27)$ & $(-0.81)$ \\
\hline \multirow[t]{2}{*}{ LINTCOV } & 8.36 & $-15.16^{*}$ & $-21.15^{*}$ & $-13.51^{*}$ & -8.32 & $-11.72^{*}$ \\
\hline & $(0.80)$ & $(-1.75)$ & $(-1.70)$ & $(-1.86)$ & $(-1.49)$ & $(-1.91)$ \\
\hline \multirow[t]{2}{*}{$C A P I T A L \times L I N T C O V$} & -1.15 & 0.84 & 1.31 & 1.03 & 0.61 & 1.04 \\
\hline & $(-1.03)$ & $(0.82)$ & $(1.01)$ & $(1.12)$ & $(0.88)$ & $(1.35)$ \\
\hline \multirow[t]{2}{*}{ VOL } & -0.99 & 0.10 & 1.51 & 0.31 & $2.05^{* * *}$ & $2.04 * * *$ \\
\hline & $(-0.68)$ & $(0.11)$ & $(1.59)$ & $(0.44)$ & $(4.64)$ & $(4.93)$ \\
\hline \multirow[t]{2}{*}{$C A P I T A L \times V O L$} & 0.15 & 0.14 & -0.07 & $0.14^{* *}$ & -0.09 & -0.06 \\
\hline & $(0.79)$ & $(1.40)$ & $(-0.63)$ & $(2.06)$ & $(-1.54)$ & $(-1.07)$ \\
\hline \multirow[t]{2}{*}{ PDEFAULT } & $145.44^{* * *}$ & $90.01^{* * *}$ & $172.64^{* * *}$ & $106.28 * * *$ & $102.37^{* * *}$ & $67.13^{* * *}$ \\
\hline & $(3.08)$ & $(4.56)$ & $(4.84)$ & $(6.86)$ & $(5.72)$ & (4.19) \\
\hline$B B B S P D$ & 4.00 & 19.28 & 24.02 & $38.82^{* * *}$ & $45.23^{* * *}$ & 24.58 \\
\hline & $(0.25)$ & $(1.17)$ & $(1.15)$ & $(2.70)$ & $(2.95)$ & $(1.48)$ \\
\hline$B B B S P D \times L I N T C O V$ & $-11.78^{* *}$ & $-9.28^{* *}$ & -8.24 & $-10.24^{* * *}$ & $-8.99 * * *$ & $-7.63^{* * *}$ \\
\hline & $(-2.46)$ & $(-2.26)$ & $(-1.52)$ & $(-3.57)$ & $(-3.84)$ & $(-3.13)$ \\
\hline$B B B S P D \times V O L$ & $0.97^{* *}$ & 0.28 & -0.19 & -0.16 & $-0.41^{* *}$ & $-0.52^{* * *}$ \\
\hline & $(2.19)$ & $(1.05)$ & $(-0.40)$ & $(-0.61)$ & $(-2.54)$ & $(-3.53)$ \\
\hline Constant & 160.64 & $159.34^{* *}$ & $353.31^{* * *}$ & $335.46^{* * *}$ & $160.30^{* * *}$ & $295.13^{* * *}$ \\
\hline & $(1.34)$ & $(2.49)$ & $(3.23)$ & $(5.76)$ & $(2.81)$ & $(4.22)$ \\
\hline Observations & 3029 & 7492 & 3498 & 12034 & 8618 & 5874 \\
\hline R-squared & 0.634 & 0.668 & 0.690 & 0.627 & 0.641 & 0.639 \\
\hline $\mathrm{p}$ value for $H_{0}$ : & & & & & & \\
\hline$\delta_{1}+\delta_{2} \times L I N \bar{T} C O V+\delta_{3} \times V \bar{O} L=0$ & 0.6770 & 0.3141 & 0.4002 & 0.3898 & 0.0464 & 0.0975 \\
\hline$\delta_{1}+\delta_{2} \times(L I N \bar{T} C O V-\sigma)+\delta_{3} \times V \bar{O} L=0$ & 0.4366 & 0.2202 & 0.2003 & 0.1506 & 0.0370 & 0.0409 \\
\hline$\delta_{1}+\delta_{2} \times(L I N \bar{T} C O V+\sigma)+\delta_{3} \times V \bar{O} L=0$ & 0.8485 & 0.6720 & 0.8514 & 0.9070 & 0.2685 & 0.5736 \\
\hline
\end{tabular}

$\bar{a}$ The dependent variable is LOAN SPREAD: Loan spread over LIBOR at the time of the loan origination. Model 1 in the top (bottom) panel reports the results for loans of borrowers without (with) a commercial paper 
rating; Model 2 in the top (bottom) pane; reports the results for loans of borrowers without (with) a credit rating; Model 3 in the top (bottom) panel reports the results for loans of borrowers that did not issue (issued) a public bond in the last three years; Model 4 in the top (bottom) panel reports the results for loans taken out from a single (multiple) bank(s); Model 5 in the top (bottom) reports the results for loans taken out from a bank that extended more than (less or equal) 50 percent of the loans the borrower took out over the last three years; Model 6 in the top (bottom) reports the results for loans taken out from a bank that extended 75 (25) percent or more (less) of the loans the borrower took out over the last three years. Included in the regressions are all of the firm, loan and bank controls used in model 3 of Table 3 , as well as time (year-quarter) fixed effects and dummy variables for the issuer's sector of activity as defined by SIC one-digit code. See Appendix 1 for the definitions of all controls included in the models. Models estimated with bank fixed effects, and robust standard errors, clustered by firm and by bank. We report t statistics in parentheses. *** denotes $1 \%$ significant level, ** denotes $5 \%$ significant level, and * denotes $10 \%$ significant level. 
Table 8 Loan spread, bank capital, and borrowers cash flow and risk (BETA): Dep vs. nondep borrowers ${ }^{a}$

\begin{tabular}{|c|c|c|c|c|c|c|}
\hline & & & & & & \\
\hline Variables & 1 & 2 & 3 & 4 & 5 & 6 \\
\hline CAPITAL & $\begin{array}{r}-5.73^{* * *} \\
(-3.43)\end{array}$ & $\begin{array}{r}-5.66^{* * *} \\
(-2.82)\end{array}$ & $\begin{array}{r}-4.91^{* * *} \\
(-2.86)\end{array}$ & $\begin{array}{r}-6.33^{* * *} \\
(-2.66)\end{array}$ & $\begin{array}{r}-5.86^{* *} \\
(-2.20)\end{array}$ & $\begin{array}{r}-6.08^{* *} \\
(-2.13)\end{array}$ \\
\hline LINTCOV & $\begin{array}{r}-26.18^{* * *} \\
(-5.13)\end{array}$ & $\begin{array}{r}-24.42^{* * *} \\
(-4.86)\end{array}$ & $\begin{array}{r}-23.12^{* * *} \\
(-4.70)\end{array}$ & $\begin{array}{r}-22.63^{* * * *} \\
(-4.72)\end{array}$ & $\begin{array}{r}-34.04^{* * * *} \\
(-4.04)\end{array}$ & $\begin{array}{r}-28.39^{* * *} \\
(-3.77)\end{array}$ \\
\hline$C A P I T A L \times L I N T C O V$ & $\begin{array}{r}2.34^{* * * *} \\
(3.84)\end{array}$ & $\begin{array}{r}2.29^{* * *} \\
(3.64)\end{array}$ & $\begin{array}{r}2.08^{* * *} \\
(3.56)\end{array}$ & $\begin{array}{r}1.79^{* * *} \\
(2.79)\end{array}$ & $\begin{array}{r}3.09^{* * *} \\
(2.96)\end{array}$ & $\begin{array}{r}2.44^{* * *} \\
(2.68)\end{array}$ \\
\hline BETA & $\begin{array}{r}29.19^{* *} \\
(2.27)\end{array}$ & $\begin{array}{r}32.49^{* *} \\
(2.37)\end{array}$ & $\begin{array}{r}28.94^{* *} \\
(2.30)\end{array}$ & $\begin{array}{r}26.01 \\
(1.62)\end{array}$ & $\begin{array}{r}45.99^{* * *} \\
(2.80)\end{array}$ & $\begin{array}{r}46.75^{* * * *} \\
(2.68)\end{array}$ \\
\hline$C A P I T A L \times B E T A$ & $\begin{array}{c}-3.29 * * \\
(-2.32)\end{array}$ & $\begin{array}{c}-3.72^{* *} \\
(-2.36)\end{array}$ & $\begin{array}{r}-3.62^{* *} \\
(-2.55)\end{array}$ & $\begin{array}{r}-2.49 \\
(-1.25)\end{array}$ & $\begin{array}{r}-4.68^{* *} \\
(-2.36)\end{array}$ & $\begin{array}{l}-4.17^{*} \\
(-1.90)\end{array}$ \\
\hline$B B B S P D$ & $\begin{array}{c}17.74 \\
(1.39)\end{array}$ & $\begin{array}{r}12.65 \\
(0.78)\end{array}$ & $\begin{array}{r}18.62 \\
(1.36)\end{array}$ & $\begin{array}{r}-6.64 \\
(-0.27)\end{array}$ & $\begin{array}{r}28.34^{*} \\
(1.91)\end{array}$ & $\begin{array}{r}30.23^{*} \\
(1.73)\end{array}$ \\
\hline$B B B S P D \times L I N T C O V$ & $\begin{array}{r}-7.28^{* * *} \\
(-3.19)\end{array}$ & $\begin{array}{c}-5.60 * * \\
(-2.43)\end{array}$ & $\begin{array}{r}-7.49^{* * *} \\
(-3.33)\end{array}$ & $\begin{array}{r}-2.47 \\
(-1.00)\end{array}$ & $\begin{array}{l}-6.09^{*} \\
(-1.87)\end{array}$ & $\begin{array}{l}-6.29^{*} \\
(-1.82)\end{array}$ \\
\hline$B B B S P D \times B E T A$ & $\begin{array}{r}1.28 \\
(0.25) \\
\end{array}$ & $\begin{array}{r}5.63 \\
(0.93) \\
\end{array}$ & $\begin{array}{r}4.22 \\
(0.80) \\
\end{array}$ & $\begin{array}{r}4.27 \\
(0.58)\end{array}$ & $\begin{array}{r}-4.28 \\
(-0.67) \\
\end{array}$ & $\begin{array}{l}-10.28 \\
(-1.54)\end{array}$ \\
\hline Constant & $\begin{array}{r}414.70^{* * *} \\
(7.97)\end{array}$ & $\begin{array}{r}448.62^{* * *} \\
(6.77)\end{array}$ & $\begin{array}{r}398.61^{* * *} \\
(7.56)\end{array}$ & $\begin{array}{r}494.06^{* * *} \\
(3.21)\end{array}$ & $\begin{array}{r}409.00^{* * *} \\
(5.32)\end{array}$ & $\begin{array}{r}420.69^{* * *} \\
(4.98)\end{array}$ \\
\hline $\begin{array}{l}\text { Observations } \\
\text { R-squared }\end{array}$ & $\begin{array}{r}12928 \\
0.543\end{array}$ & $\begin{array}{r}8469 \\
0.555\end{array}$ & $\begin{array}{r}12459 \\
0.583\end{array}$ & $\begin{array}{r}3936 \\
0.567\end{array}$ & $\begin{array}{r}6777 \\
0.634\end{array}$ & $\begin{array}{r}5517 \\
0.646\end{array}$ \\
\hline $\begin{array}{l}\mathrm{p} \text { value for } H_{0} \text { : } \\
\delta_{1}+\delta_{2} \times L I N \bar{T} C O V+\delta_{3} \times B \overline{E T A}=0 \\
\delta_{1}+\delta_{2} \times(L I N \bar{T} C O V-\sigma)+\delta_{3} \times B \overline{E T} A=0 \\
\delta_{1}+\delta_{2} \times(L I N \bar{T} C O V+\sigma)+\delta_{3} \times B \overline{E T} A=0\end{array}$ & $\begin{array}{l}0.0010 \\
0.0000 \\
0.6621\end{array}$ & $\begin{array}{l}0.0147 \\
0.0000 \\
0.9674 \\
\end{array}$ & $\begin{array}{l}0.0037 \\
0.0000 \\
0.6707\end{array}$ & $\begin{array}{l}0.0055 \\
0.0002 \\
0.2069\end{array}$ & $\begin{array}{l}0.0694 \\
0.0003 \\
0.6492 \\
\end{array}$ & $\begin{array}{l}0.0134 \\
0.0003 \\
0.6362 \\
\end{array}$ \\
\hline Panel B: Non-dependent borrowers & & & & & & \\
\hline Variables & 1 & 2 & 3 & 4 & 5 & 6 \\
\hline CAPITAL & $\begin{array}{r}1.71 \\
(0.45)\end{array}$ & $\begin{array}{r}-0.26 \\
(-0.09)\end{array}$ & $\begin{array}{r}-6.26 \\
(-1.48)\end{array}$ & $\begin{array}{r}-0.78 \\
(-0.35)\end{array}$ & $\begin{array}{r}-2.32 \\
(-1.23)\end{array}$ & $\begin{array}{r}-2.02 \\
(-0.89)\end{array}$ \\
\hline LINTCOV & $\begin{array}{l}17.88 \\
(1.46)\end{array}$ & $\begin{array}{r}-8.06 \\
(-0.72)\end{array}$ & $\begin{array}{r}-25.70^{*} \\
(-1.87)\end{array}$ & $\begin{array}{l}-12.64 \\
(-1.53)\end{array}$ & $\begin{array}{r}-16.20^{* * * *} \\
(-2.67)\end{array}$ & $\begin{array}{r}-18.79^{* * *} \\
(-2.98)\end{array}$ \\
\hline$C A P I T A L \times L I N T C O V$ & $\begin{array}{r}-2.12 \\
(-1.53)\end{array}$ & $\begin{array}{r}-0.01 \\
(-0.01)\end{array}$ & $\begin{array}{r}1.95 \\
(1.32)\end{array}$ & $\begin{array}{r}0.76 \\
(0.76)\end{array}$ & $\begin{array}{c}1.26^{*} \\
(1.74)\end{array}$ & $\begin{array}{r}1.59^{* *} \\
(2.06)\end{array}$ \\
\hline BETA & $\begin{array}{l}-43.05 \\
(-1.64)\end{array}$ & $\begin{array}{r}9.49 \\
(0.38)\end{array}$ & $\begin{array}{r}4.40 \\
(0.14)\end{array}$ & $\begin{array}{r}18.92 \\
(1.24)\end{array}$ & $\begin{array}{r}28.41^{*} \\
(1.90)\end{array}$ & $\begin{array}{r}38.43^{* * *} \\
(2.61)\end{array}$ \\
\hline$C A P I T A L \times B E T A$ & $\begin{array}{r}5.10 \\
(1.55)\end{array}$ & $\begin{array}{r}-1.30 \\
(-0.48)\end{array}$ & $\begin{array}{r}1.08 \\
(0.32)\end{array}$ & $\begin{array}{r}-2.31 \\
(-1.36)\end{array}$ & $\begin{array}{r}-4.32^{* *} \\
(-2.56)\end{array}$ & $\begin{array}{r}-5.57^{* * *} \\
(-3.08)\end{array}$ \\
\hline$B B B S P D$ & $\begin{array}{r}24.21 \\
(1.19)\end{array}$ & $\begin{array}{r}26.66 \\
(1.54)\end{array}$ & $\begin{array}{r}22.79 \\
(1.24)\end{array}$ & $\begin{array}{r}31.85^{* *} \\
(2.40)\end{array}$ & $\begin{array}{r}19.60 \\
(1.32)\end{array}$ & $\begin{array}{r}-5.79 \\
(-0.34)\end{array}$ \\
\hline$B B B S P D \times L I N T C O V$ & $\begin{array}{r}-12.45^{* * *} \\
(-2.68)\end{array}$ & $\begin{array}{r}-10.85^{* *} \\
(-2.41)\end{array}$ & $\begin{array}{r}-6.69 \\
(-1.19)\end{array}$ & $\begin{array}{r}-10.96^{* * *} \\
(-3.64)\end{array}$ & $\begin{array}{r}-7.70^{* * *} \\
(-3.21)\end{array}$ & $\begin{array}{r}-6.23^{* *} \\
(-2.50)\end{array}$ \\
\hline$B B B S P D \times B E T A$ & $\begin{array}{r}15.35^{* *} \\
(2.16)\end{array}$ & $\begin{array}{r}4.84 \\
(0.67) \\
\end{array}$ & $\begin{array}{r}-5.95 \\
(-0.59) \\
\end{array}$ & $\begin{array}{r}4.82 \\
(0.82) \\
\end{array}$ & $\begin{array}{r}10.33^{*} \\
(1.82) \\
\end{array}$ & $\begin{array}{r}9.16 \\
(1.54) \\
\end{array}$ \\
\hline Constant & $\begin{array}{r}-9.34 \\
(-0.12)\end{array}$ & $\begin{array}{r}50.73 \\
(0.69)\end{array}$ & $\begin{array}{r}307.69^{* * *} \\
(3.19)\end{array}$ & $\begin{array}{r}352.55^{* * *} \\
(6.13)\end{array}$ & $\begin{array}{r}345.70^{* * *} \\
(5.67)\end{array}$ & $\begin{array}{r}384.08^{* * *} \\
(5.33)\end{array}$ \\
\hline Observations & 3025 & 7484 & 3494 & 12017 & 8602 & 5858 \\
\hline R-squared & 0.618 & 0.659 & 0.688 & 0.618 & 0.634 & 0.630 \\
\hline $\begin{array}{l}\mathrm{p} \text { value for } H_{0}: \\
\delta_{1}+\delta_{2} \times L I N \bar{T} C O V+\delta_{3} \times B \overline{E T A}=0 \\
\delta_{1}+\delta_{2} \times(L I N \bar{T} C O V-\sigma)+\delta_{3} \times B \overline{E T} A=0 \\
\delta_{1}+\delta_{2} \times(L I N \bar{T} C O V+\sigma)+\delta_{3} \times B \overline{E T} A=0\end{array}$ & $\begin{array}{l}0.6122 \\
0.2555 \\
0.5524 \\
\end{array}$ & $\begin{array}{l}0.3102 \\
0.4600 \\
0.3936\end{array}$ & $\begin{array}{l}0.2963 \\
0.1905 \\
0.9261 \\
\end{array}$ & $\begin{array}{l}0.3985 \\
0.2564 \\
0.9254 \\
\end{array}$ & $\begin{array}{l}0.0090 \\
0.0027 \\
0.2580 \\
\end{array}$ & $\begin{array}{l}0.0336 \\
0.0059 \\
0.5852 \\
\end{array}$ \\
\hline
\end{tabular}

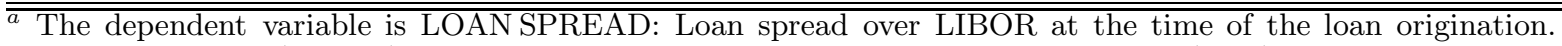
Model 1 in the top (bottom) panel reports the results for loans of borrowers without (with) a commercial paper rating; Model 2 in the top (bottom) panel reports the results for loans of borrowers without (with) a credit rating; Model 3 in the top (bottom) panel reports the results for loans of borrowers that did not issue (issued) a public bond in the last three years; Model 4 in the top (bottom) panel reports the results for loans taken out from a single (multiple) bank(s); Model 5 in the top (bottom) reports the results for loans taken out from a 
bank that extended more than (less or equal) 50 percent of the loans the borrower took out over the last three years; Model 6 in the top (bottom) reports the results for loans taken out from a bank that extended 75 (25) percent or more (less) of the loans the borrower took out over the last three years. Included in the regressions are all of the firm, loan and bank controls used in model 3 of Table 3, as well as time (year-quarter) fixed effects and dummy variables for the issuer's sector of activity as defined by SIC one-digit code. See Appendix 1 in the paper for the definitions of all controls included in the models. Models estimated with bank fixed effects, and robust standard errors, clustered by firm and by bank. We report t statistics in parentheses. *** denotes $1 \%$ significant level, ** denotes $5 \%$ significant level, and * denotes $10 \%$ significant level. 
Table 9 Loan spread and bank capital: Results of a two-stage test ${ }^{a}$

\begin{tabular}{lrrr}
\hline \hline Variables & \multicolumn{1}{c}{1} & \multicolumn{1}{c}{3} \\
\hline CAPITAL & $11.648^{* * *}$ & $11.526^{* * *}$ & $11.578^{* * *}$ \\
& $(7.35)$ & $(7.17)$ & $(8.15)$ \\
\hline Constant & $100.765^{* * *}$ & $101.811^{* * *}$ & $97.583^{* * *}$ \\
& $(7.47)$ & $(7.44)$ & $(8.05)$ \\
Observations & 15985 & 15985 & 15985 \\
R-squared & 0.128 & 0.111 & 0.110 \\
\hline \hline
\end{tabular}

${ }^{a}$ In the first stage we estimate our model of loan spreads controlling for the controls as reported in Table 3, except the bank's capital-to-asset ratio. See the internet appendix to this paper for the results of first stage. In the second stage, we regress the predicted spread estimated in the first stage on the bank's capital-to-assets ratio. Models follow the same order of the models reported in Table 3, and use the estimation approach (in both stages) we adopt in that table (models 1 and 2 are pooled results, and model 3 is estimated with bank fixed effects). See Appendix 1 for the definitions of all controls included in the models. Models estimated with robust standard errors, clustered by firm and by bank. We report t statistics in parentheses. $* * *$ denotes $1 \%$ significant level, ** denotes $5 \%$ significant level, and * denotes $10 \%$ significant level. 
Table 10 Loan spread, bank capital and borrowers' cash flow ${ }^{a}$

Single model of bank dependent and non-dependent borrowers

\begin{tabular}{|c|c|c|c|c|c|c|}
\hline Variables & 1 & 2 & 3 & 4 & 5 & 6 \\
\hline \multirow[t]{2}{*}{ NONDEP } & $-86.37^{* * *}$ & $-57.46^{* * *}$ & 10.75 & $-119.15^{* * *}$ & $-26.21^{*}$ & -18.10 \\
\hline & $(-3.00)$ & $(-3.64)$ & $(0.49)$ & $(-6.88)$ & $(-1.74)$ & $(-1.06)$ \\
\hline \multirow[t]{2}{*}{ LINTCOV } & $-26.12^{* * *}$ & $-24.88^{* * *}$ & $-23.04^{* * *}$ & $-30.35^{* * *}$ & $-31.81^{* * *}$ & $-25.69^{* * *}$ \\
\hline & $(-7.10)$ & $(-6.28)$ & $(-6.25)$ & $(-5.91)$ & $(-6.07)$ & $(-4.38)$ \\
\hline \multirow[t]{2}{*}{ PDEFAULT } & $79.75^{* * *}$ & $86.31^{* * *}$ & $69.74^{* * *}$ & $50.82^{* * *}$ & $87.89^{* * *}$ & $70.23^{* * *}$ \\
\hline & $(11.63)$ & (9.33) & $(9.73)$ & $(4.17)$ & (9.97) & $(6.61)$ \\
\hline \multirow[t]{2}{*}{ VOL } & $0.99^{* * *}$ & $0.75 * * *$ & $1.06^{* * *}$ & $0.86^{* * *}$ & $1.02^{* * *}$ & $1.04^{* * *}$ \\
\hline & $(16.08)$ & $(10.74)$ & $(16.94)$ & $(9.45)$ & $(13.37)$ & $(11.73)$ \\
\hline \multirow[t]{2}{*}{ NONDEP $x$ CAPITAL } & $8.30 * *$ & $6.22^{* * *}$ & -0.05 & $10.47^{* * *}$ & 1.23 & -0.59 \\
\hline & $(2.43)$ & $(3.31)$ & $(-0.02)$ & $(4.86)$ & $(0.65)$ & $(-0.27)$ \\
\hline \multirow[t]{2}{*}{ NONDEP $\mathrm{x}$ LINTCOV } & $37.09 * * *$ & 4.11 & 4.95 & $17.75^{* * *}$ & $17.86^{* * *}$ & 9.08 \\
\hline & $(3.02)$ & $(0.62)$ & $(0.46)$ & $(2.58)$ & $(2.66)$ & $(1.21)$ \\
\hline \multirow[t]{2}{*}{ NONDEP x PDEFAULT } & $116.58^{* * *}$ & $-25.85^{* *}$ & $98.53^{* * *}$ & $43.16^{* * *}$ & 0.46 & $-23.48^{*}$ \\
\hline & $(4.05)$ & $-2.14)$ & $(5.90)$ & $(3.24)$ & $(0.04)$ & $(-1.68)$ \\
\hline \multirow[t]{2}{*}{ NONDEP $\mathrm{x}$ VOL } & $0.98^{* * *}$ & $1.24^{* * *}$ & 0.24 & $0.34^{* * *}$ & -0.01 & 0.10 \\
\hline & $(4.30)$ & $(10.61)$ & $(1.54)$ & $(3.20)$ & $(-0.08)$ & $(0.97)$ \\
\hline \multirow[t]{2}{*}{ LINTCOV x CAPITAL } & $2.40^{* * *}$ & $2.22^{* * *}$ & $2.09^{* * *}$ & $2.62^{* * *}$ & $2.82^{* * *}$ & $1.91^{* * *}$ \\
\hline & $(5.39)$ & $(4.58)$ & $(4.72)$ & $(4.03)$ & $(4.38)$ & $(2.59)$ \\
\hline \multirow[t]{2}{*}{ NONDEP $x$ LINTCOV x CAPITAL } & $-3.75^{* * *}$ & $-1.38^{*}$ & -0.32 & $-1.76^{* *}$ & $-1.56^{*}$ & -0.18 \\
\hline & $(-2.63)$ & $(-1.82)$ & $(-0.24)$ & $(-2.07)$ & $(-1.89)$ & $(-0.19)$ \\
\hline \multirow[t]{2}{*}{ BBBSPD } & $31.08^{* * *}$ & $30.35^{* * *}$ & $32.43^{* * *}$ & 0.84 & $24.42^{* * *}$ & 11.51 \\
\hline & $(3.52)$ & $(3.20)$ & $(3.69)$ & $(0.08)$ & $(2.60)$ & $(1.03)$ \\
\hline \multirow[t]{2}{*}{ BBBSPD x NONDEP } & $-18.25^{*}$ & $-11.68^{*}$ & $-20.16^{* *}$ & $36.99^{* * *}$ & 9.91 & 8.57 \\
\hline & $(-1.87)$ & $(-1.66)$ & $(-2.17)$ & $(4.82)$ & $(1.61)$ & $(1.19)$ \\
\hline \multirow[t]{2}{*}{ BBBSPD x LINTCOV } & $-7.62^{* * *}$ & $-6.77^{* * *}$ & $-8.00^{* * *}$ & -1.12 & $-6.31^{* * *}$ & $-5.39 * *$ \\
\hline & $(-5.11)$ & $(-3.90)$ & $(-5.53)$ & $(-0.46)$ & $(-3.23)$ & $(-2.52)$ \\
\hline \multirow[t]{2}{*}{ BBBSPD x NONDEP x LINTCOV } & -3.05 & -1.72 & -0.43 & $-9.17 * * *$ & -2.77 & -2.84 \\
\hline & $(-0.74)$ & $(-0.56)$ & $(-0.10)$ & $(-3.12)$ & $(-1.04)$ & $(-0.95)$ \\
\hline \multirow[t]{2}{*}{ constant } & $200.27^{* *}$ & $257.09^{* *}$ & $206.18^{* *}$ & $216.11^{* *}$ & $214.04^{* *}$ & $202.42^{* *}$ \\
\hline & $(2.03)$ & $(2.55)$ & $(2.09)$ & $(2.19)$ & $(2.31)$ & $(1.97)$ \\
\hline Observations & 15985 & 15985 & 15985 & 15985 & 15411 & 11406 \\
\hline R-squared & 0.707 & 0.694 & 0.706 & 0.708 & 0.708 & 0.723 \\
\hline \multicolumn{7}{|l|}{$\mathrm{p}$ value for $H_{0}:^{b}$} \\
\hline$\delta_{1}+\delta_{2}=0$ & 0.3217 & 0.2325 & 0.1678 & 0.1247 & 0.0224 & 0.0076 \\
\hline
\end{tabular}

$a$ The dependent variable is LOAN SPREAD: Loan spread over LIBOR at the time of the loan origination. NONDEP is a dummy variable equal to one if the borrower does not dependent on the lender for funding, with non dependence defined as follows: Model 1, the borrower has a commercial paper rating; Model 2, the borrower has a credit rating; Model 3, the borrower issued a public bond in the last three years; Model 4, the loan was taken out from multiple banks; Model 5, the loan was taken out from a bank that extended less or equal to 50 percent of the loans the borrower took out over the last three years; Model 6, the loan was taken out from a bank that extended 25 percent or less of the loans the borrower took out over the last three years. In the latter model the control group are the loans taken out from a bank that extended 75 percent or more of the loans the borrower took out over the last three years. Included in the regressions, are all of the firm, loan and bank controls used in model 3 of Table 3, as well as time (year-quarter) fixed effects and dummy variables for the issuer's sector of activity as defined by SIC one-digit code. See Appendix 1 for the definitions of all controls included in the models. Models estimated with bank-time (year-quarter) fixed effects, and robust standard errors, clustered by firm and by bank. We report t statistics in parentheses. *** denotes $1 \%$ significant level, $* *$ denotes $5 \%$ significant level, and * denotes $10 \%$ significant level.

${ }^{b} \delta_{1}$ and $\delta_{2}$ are the estimated coefficients on $L I N T C O V \times C A P I T A L$ and $N O N D E P \times L I N T C O V \times C A P I T A L$, respectively. 
Table 11 Loan spread, bank capital, and borrowers' cash flow: Dep vs nondep borrowers ${ }^{a}$ No other controls except fixed effects

\begin{tabular}{|c|c|c|c|c|c|c|}
\hline \multicolumn{7}{|c|}{ Panel A: Bank-dependent borrowers } \\
\hline Variables & 1 & 2 & 3 & 4 & 5 & 6 \\
\hline \multirow[t]{2}{*}{ LINTCOV } & $-27.62^{* * *}$ & $-29.21^{* *}$ & $-23.36^{* *}$ & $-65.51^{* * *}$ & $-27.83^{* *}$ & $-29.69^{* *}$ \\
\hline & $(-3.05)$ & $(-2.10)$ & $(-2.41)$ & $(-2.63)$ & $(-2.56)$ & $(-2.25)$ \\
\hline \multirow[t]{2}{*}{ CAPITAL x LINTCOV } & $2.79^{* * *}$ & $3.44^{* *}$ & $2.29^{* *}$ & $10.35^{* * *}$ & $2.34^{*}$ & 1.61 \\
\hline & $(2.63)$ & $(2.03)$ & $(2.05)$ & $(2.99)$ & $(1.70)$ & $(0.91)$ \\
\hline \multirow[t]{2}{*}{ BBBSPD } & $71.65^{* * *}$ & $46.56^{* *}$ & $59.57^{* * *}$ & $159.01^{* *}$ & $31.92^{*}$ & 16.15 \\
\hline & $(4.82)$ & $(2.25)$ & $(3.99)$ & $(2.36)$ & $(1.93)$ & $(0.85)$ \\
\hline \multirow[t]{2}{*}{ BBBSPD x LINTCOV } & $-18.65^{* * *}$ & $-18.67^{* * *}$ & $-17.85^{* * *}$ & $-25.02^{* *}$ & $-12.20 * * *$ & $-8.52^{* *}$ \\
\hline & $(-6.53)$ & $(-5.01)$ & $(-6.55)$ & $(-2.46)$ & $(-3.92)$ & $(-2.42)$ \\
\hline Observations & 10839 & 6409 & 10347 & 2048 & 5782 & 4626 \\
\hline R-squared & 0.798 & 0.858 & 0.829 & 0.919 & 0.880 & 0.894 \\
\hline \multicolumn{7}{|c|}{ Panel B: Non-dependent borrowers } \\
\hline Variables & 1 & 2 & 3 & 4 & 5 & 6 \\
\hline \multirow[t]{2}{*}{ LINTCOV } & 1.60 & -14.53 & 4.40 & $-26.44^{* * *}$ & -3.49 & 13.97 \\
\hline & $(0.13)$ & $(-1.20)$ & $(0.26)$ & $(-2.73)$ & $(-0.42)$ & $(1.22)$ \\
\hline \multirow[t]{2}{*}{ CAPITAL x LINTCOV } & -0.93 & -0.98 & -3.03 & $2.31^{* *}$ & -0.23 & $-3.31^{* *}$ \\
\hline & $(-0.78)$ & $(-0.74)$ & $(-1.50)$ & $(2.08)$ & $(-0.25)$ & $(-2.49)$ \\
\hline \multirow[t]{2}{*}{ BBBSPD } & $62.89^{* * *}$ & $63.63^{* * *}$ & $76.14^{* * *}$ & $68.03^{* * *}$ & $82.06^{* * *}$ & 17.97 \\
\hline & $(3.18)$ & $(3.85)$ & (3.03) & $(5.27)$ & $(5.59)$ & $(0.81)$ \\
\hline \multirow[t]{2}{*}{ BBBSPD x LINTCOV } & $-11.27 * *$ & $-17.74^{* * *}$ & $-20.72^{* * *}$ & $-19.57^{* * *}$ & $-20.48^{* * *}$ & $-14.91^{* * *}$ \\
\hline & $(-2.34)$ & $(-3.78)$ & $(-2.78)$ & $(-5.89)$ & $(-6.95)$ & $(-3.63)$ \\
\hline Observations & 2753 & 6844 & 3044 & 10791 & 6259 & 3308 \\
\hline R-squared & 0.754 & 0.807 & 0.836 & 0.803 & 0.834 & 0.872 \\
\hline
\end{tabular}

${ }^{a}$ The dependent variable is LOAN SPREAD: Loan spread over LIBOR at the time of the loan origination. Model 1 in the top (bottom) panel reports the results for loans of borrowers without (with) a commercial paper rating; Model 2 in the top (bottom) panel reports the results for loans of borrowers without (with) a credit rating; Model 3 in the top (bottom) panel reports the results for loans of borrowers that did not issue (issued) a public bond in the last three years; Model 4 in the top (bottom) panel reports the results for loans taken out from a single (multiple) bank(s); Model 5 in the top (bottom) reports the results for loans taken out from a bank that extended more than (less or equal) 50 percent of the loans the borrower took out over the last three years; Model 6 in the top (bottom) reports the results for loans taken out from a bank that extended 75 (25) percent or more (less) of the loans the borrower took out over the last three years. See Appendix 1 in the paper for the definitions of all controls included in the models. Models do not included any additional controls, and are estimated with bank-time (year-quarter) and borrower fixed effects, and robust standard errors, clustered by firm and by bank. We report $\mathrm{t}$ statistics in parentheses. $* * *$ denotes $1 \%$ significant level, ** denotes $5 \%$ significant level, and $*$ denotes $10 \%$ significant level. 